\title{
Big 4 Audit Fee Premiums for National and City-Specific Industry Leadership in the United Kingdom: Additional Evidence
}

\begin{abstract}
This study investigates the relationship between Big 4 auditor industry specialisation and audit pricing in the U.K. in a period of many changes having taken place in the market for audit services. Using a large dataset between 2004 and 2011, our empirical results show a significantly higher fee premium for the Big 4 firms who are national industry leaders as compared to city-specific industry leaders, and that the fee premium for industry leadership is only earned by the city-specific industry leaders if and when they are also the national leaders. Neither the national nor city level industry leadership alone is priced anymore in the U.K. audit market. These findings hold for the pre- and the post-GFC period only and for a number of additional analyses. The evidence suggests that the Big 4 industry leadership in the U.K. has moved away from the previously documented premium for the Big 4 city-specific industry leadership alone, and is now driven solely by the joint Big 4 industry expertise at the national and cityspecific levels concurrently. The study's results indicate that there is a progression from city-specific industry expertise to national-specific industry expertise, and they imply that there has been an improvement in the sharing and transferability of industry knowledge and expertise among the city offices of the Big 4 firms in the U.K. in the period of investigation.
\end{abstract}

Keywords: Audit fees, independence, external audit, auditor reputation, audit market 


\section{Big 4 Audit Fee Premiums for National and City-Specific Industry Leadership in the United Kingdom: Additional Evidence}

\section{Introduction}

In the aftermath of major accounting and audit scandals at the start of the century, regulators and audit professionals have been seeking to regain the confidence of financial statements' users. The market of audit services globally has changed significantly in the recent years, and especially after the Global Financial Crisis (GFC), as more and more initiatives are being explored by the regulators and the accounting profession in an effort to enhance the quality of the information in the markets. Using a sample of non-financial publicly listed companies in the U.K. for the period 2004-2011, we explore whether the previous documented audit fee premium earned by Big 4 industry specialists ${ }^{1}$ holds in the pre- and post-GFC periods and during the GFC, given the various regulatory interventions at the U.K. and E.U. levels, the impact of the GFC, and other global advances in technology and recruitment.

The relationship between the audit fee premium/discount and industry specialisation is an interesting and controversial research area globally. Research studies concerning this area have mainly examined the U.S. (e.g., Hogan and Jeter, 1999; Francis et al., 2005), U.K. (e.g. Basioudis and Francis, 2007) and Australia (e.g., Craswell et al., 1995), and some other jurisdictions like Hong Kong (DeFond et al., 2000) and New Zealand (Hay and Jeter, 2011). Auditor industry specialisation is recognised as a form of auditor competency in delivering high quality audits (DeFond and Zhang, 2014), given their superior knowledge of the industry's business and accounting practices than non-specialists (Habib, 2011). The merger of the Big $\mathrm{N}$ accounting firms into the current Big 4 firms was partly driven by their intention to focus on industry specialisation $(\mathrm{GAO}, 2003)$, and the establishment of industry specialist status is seen as an important strategy in order for the audit firm to signal their ability to provide higher audit quality.

Since 2002, the passing of Sarbanes-Oxley Act in the U.S. and the various other regulatory reforms emanated by the European Union (E.U.) or the U.K. government have instigated some dramatic changes in the capital market in the U.K., in an attempt to enhance the quality of corporate governance, financial reporting and the audit function. These include the establishment of the Professional Oversight Board (POB) in 2004 by the U.K. regulator, the Financial Reporting Council (FRC), through the Audit Inspection Unit (AIU), with the responsibility to review the quality of audits performed on the public listed companies, and the mandatory adoption of the International Financial Reporting Standards (IFRS) for all listed companies in 2005. 
The GFC in 2007-2008 has provoked the investigation of the concentration and competition in the audit market by the House of Lords and the Office of Fair Trading in the U.K., and the issuance of the U.K. Corporate Governance Code in 2010 (revised in 2012 and 2014), the U.K. Stewardship Code (revised in 2012) and the Audit Firm Governance Code (revised in 2016) by the FRC.

In light of these regulatory developments and declining economic conditions due to GFC, it is plausible to assume that audit firms might have changed their structure, norms and the way they operate to respond to this more challenging business and audit environment (Firth, 2002; Srinidhi and Gul, 2007). Nonetheless, the impact of macroeconomic changes, and especially the GFC, on audit pricing is largely unknown when compared to the pre-GFC period which suggests a need for further research in this area.

Past experience also suggests that audit firms and capital markets adapt themselves differently after regulatory changes and major economic downturns (Economist, 2013; Chin, 2014). We argue that not all audit firms respond in the same way and the impact of those exogenous shocks can be diverse and unique to each firm. Consistently, prior studies in the Europe, Australia, the U.K. and the U.S. demonstrate that audit firms adjust their fees differently to reflect their changed level of audit effort in respond to the impact of GFC (Xu et al., 2013; Krishnan and Zhang, 2013; Hassan et al., 2014) and the mandatory IFRS adoption on the public listed entities (Kim et al., 2012; De George et al., 2013; Hassan et al., 2014).

Whilst these studies examined the impact of the recent changing audit environment on the generic Big 4 firms' brand name reputation, there is still absence of a research study that empirically examines the impact of these recent period developments on the Big 4 differentiation strategy through industry specialisation. In the post-Enron environment, there is some regulatory emphasis on the importance of good audit firm governance at the national level (FRC, 2010), and given the rapidly changing global and technology dependent economy and increased globalisation of the marketplace, we argue that it makes sense to assume that there may have been some pressure on audit firms to promote their national level expertise as opposed to local-office expertise. Furthermore, various interventions by the regulators and/or the accounting profession as well as other exogenous changes such as technological advances can cause changes in the specialisation investments of audit firms and which in turn may initiate progression or movement in the audit firm industry specialisation premiums observed over time.

Using a sample of non-financial publicly listed companies in the U.K. for the period 2004-2011, and applying the national-city industry specialisation framework developed by Ferguson et al. (2003), we explore whether the previous documented audit fee premium earned by Big 4 industry specialists holds in the pre-GFC (2004-2006), post-GFC (2009-2011) and during the GFC (2007-2008) periods. Contrary to prior studies, we utilise data from a longer time period and also seek to determine whether different conclusions can be drawn in the period after the GFC (i.e., the period 2009-2011) as compared to the 
U.K. evidence in prior periods (e.g. Basioudis and Francis, 2007). We conjecture that in order for the Big 4 firm to have a meaningful differentiation strategy based on industry specialisation, they need to demonstrate their ability to deliver uniform audit quality across the country within a particular industry. This is done by ensuring standardised industry expertise is being provided across the city-offices of an audit firm so as not to jeopardise or isolate any cities from this positive network externalities. Any shift in the focus of the auditor industry specialisation strategy is expected to be reflected in the changes in the industry leadership premium at the national and city level.

Interestingly, we find evidence that a fee premium for industry leadership is only earned by the Big 4 city-specific industry leaders if and when they are also national industry leaders (the premium averages at 7.1 percent), and that neither the national industry leadership alone nor the city-specific industry leadership alone is priced in the U.K. audit market anymore. These findings are in contrast to the earlier U.K. study by Basioudis and Francis (2007), indicating a shift in the way Big 4 audit firms earn audit fee premiums in the U.K. audit market. The empirical results of the current study imply that auditor industry leadership at the national (firm-wide) level and at the city-specific (office) level have both got an impact on audit pricing in the U.K. From the demand side of the market, this shows that the market intuitively perceives that the Big 4 industry expertise is only credible when the auditor is jointly the national industry leader and city-specific industry leader, and that this credibility is valued and priced in the audit market relative to national or city-specific industry leaderships alone.

Based on our present evidence, the auditor industry leadership phenomenon in the U.K. appears to be similar to Australia rather than the U.S. or New Zealand, where the fee premium only exists for joint national and city-specific industry leaders, although the results from the U.S. and Australia are quite dated. Our evidence of the industry leadership premium for Big 4 firms who are joint national and cityspecific industry leaders remains consistent using an alternative industry classification scheme, alternative definition of auditor industry leadership, dropping uncompetitive audit markets, in different sub-samples based on the client's size, risk and growth categorisation, and when using total assets and total sales as alternative measures of market shares.

Our analysis of the industry market shares shows that the top-ranked auditor per industry has on average a national market share of 59 percent of the total industry audit fees, which is higher as compared to 45 percent reported in the only prior U.K. study (Basioudis and Francis, 2007). The Big 4 national industry leaders now earn an average premium of 5.65 percent relative to the other Big 4 auditors that are not national industry leaders. In comparison to the prior U.K. evidence (Basioudis and Francis, 2007), our recent findings suggest that the Big 4 auditors have now managed to successfully market their national reputations as industry experts, which was not the case at the beginning of the $21^{\text {st }}$ century. 
At the city level, there are on average 72 unique city-industry combinations per year where the topranked auditor per industry has an average market share of 68 percent of the fees, which is comparable to the earlier findings in the U.K. and U.S. of 68 percent and 69 percent respectively (Basioudis and Francis, 2007; Francis et al., 2005). ${ }^{2}$ The average fee premium for the Big 4 city-specific industry leadership averages at 3.98 percent (but it is fading away in our sample with the passing of the years). This lower fee premium as compared to the 16 percent in Basioudis and Francis (2007) study suggests the diminishing effect of differentiated level of industry expertise between the city-offices of the Big 4 firms, as it seems the pool of industry expertise is now more centralised and equally shared at the national level.

Overall, our more up-to-date findings support the proposition that in response to the changing and more challenging audit environment in the period 2004-2011, the Big 4 audit firms have revised their industry specialisation strategy by focusing on establishing firm-wide reputations for industry expertise relative to office-level industry expertise, specifically in a country with smaller and centralised economy, like the U.K. In doing so, this allows them to achieve positive network externalities across all of their audit offices in different locations within the country, thus signal higher quality audit or added-value offered through their industry specialisation strategy.

In the next section, we provide a brief overview of the changing audit environment, a review of prior research, as well as the description of the sample, data, and audit fee model that are used in the study. This is followed by a discussion of the results of the Big 4 industry leadership tests, as well as various sensitivity analyses which are performed to confirm our initial findings. The final part of the paper concludes and discusses the implication of the research.

\section{The Changing Audit Environment}

The U.K. capital market has undergone tremendous changes since the passage of the Sarbanes-Oxley Act (2002) in the U.S. and following the numerous regulatory reforms by the E.U. and the U.K. government. All these developments demonstrate the worldwide concern and increasing demand for a more transparent and reliable financial reporting system, for a high quality external audit function and for an effective corporate governance structure. For instance, in 2003, the U.K. government's review of the Audit Regulation was carried out in response to the major audit failures and corporate collapses in the U.S. at the beginning of the century. The Professional Oversight Board (POB) was later established in 2004 by the FRC which is the U.K. independent regulator, and its main arm, the Audit Inspection Unit (AIU), was given the responsibility to review the quality of audits performed on the public listed companies. In 2005, the adoption of the International Financial Reporting Standards (IFRS) for all listed companies has been made mandatory in the U.K. by the E.U., in an effort to aid the harmonisation of 
global financial reporting practice and encourage the development of neo-liberal capital markets (Hassan et al., 2014).

Despite the highly regulated audit market, the credibility of the auditing profession has been subject to greater scrutiny during and following the period of the GFC which started in the mid- $2007^{3}$, leading, in the U.K., to the investigation of the concentration and competition in the Big 4 audit market by the House of Lords and the Office of Fair Trading. Audit quality has been a highly debatable topic since then, where auditors are particularly argued to be lacking in professional scepticism following the audit firms' failure to detect or prevent corporate collapses from happening (Sikka, 2009). Issues of poor governance and risk management exercised by all firms operating in the market for audit services have also been put under the spotlight. Reacting to these problems, in 2010, the FRC issued the U.K. Corporate Governance Code (revised in 2012 and 2014), the UK Stewardship Code (revised in 2012) and the Audit Firm Governance Code (revised in 2016). Also, in 2008, it has been made a statutory provision in the U.K. for each of the audit firms to prepare a transparency report annually and which discloses information about the audit firm's legal and governance structures, its internal quality control systems, its independence procedures and practices, and certain financial information (TCCAB, 2011). More recently, and as the regulatory interventions and changes continue, the E.U. has proposed a number of audit reforms, including mandatory audit firm rotation and elimination of non-audit services offered by the incumbent external auditor, and these reforms were to be implemented by the member states by July 2016 .

Considering the above highlighted litany of regulatory changes and developments, the declining financial conditions and the extreme economic uncertainty due to GFC, it follows that the global regulatory environment is highly dynamic, adding complexity and risk to every industry including the operation and management of the audit firms. As a result, in order for the audit firms to have developed a thorough understanding of these and other emerging drivers of change and to prepare for a range of possible future scenarios, they may have been forced to consider their business strategies, choice of geographic locations, business models and operating structures (Firth, 2002; Srinidhi and Gul, 2007). The impact of the GFC alone has caused the largest and sharpest drop in global economic activity and instigated governments and regulators to respond swiftly bailing out financial systems and individual companies.

Anecdotal evidence suggests that audit firms have differentiated themselves after the GFC transcending the traditional boundaries of the profession (Economist, 2013; Chin, 2014). Therefore, the audit firms may have modified their industry specialisation strategies as a response to the GFC and the various regulatory initiatives that took place in the first decade of the century. Whether the regulatory 
interventions, the GFC and the resulting change in audit firms' structure and market specialisation focus had a direct effect on the pricing of audit services is an appealing topic for further research.

Moreover, as the impact of those changes on all audit firms may not be the same, the responses may also not be universal across all audit firms. Changes in the regulatory environment bring together challenges for audit firms and their clients, and different organisations may employ different strategies in hoping to turn challenges into opportunities. For example, some firms may have responded to regulatory changes by providing a differentiated service, others by directing their efforts on building up new specialist expertise to serve more clients, and others by investing in technology to carry out the audit as efficiently as possible. Trends in the first decade of the century having impacted audit firms in different ways, among others, include recruitment and succession planning, competition, offshoring and outsourcing. Technology developments have altered how services are delivered by audit firms and audit firms have made diverse investments in respect of this (Attolini and Thompson, 2014). A recent case involves EY UK that joined PwC and KPMG in securing an alternative business structure licence, allowing it to provide legal services in England and Wales.

In the post-Enron environment with the demise of Arthur Andersen and the late banking crisis, the audit firms came under intense public scrutiny to respond quickly and restore economic growth through building trust. The U.K. regulators have emphasised the importance of good audit firm governance at the national level (FRC, 2010). In addition, we argue the rapidly changing global and technology dependent economy and increased globalisation of the marketplace, where different players are expected to emerge and networks to expand, have probably forced audit firms to shift their focus to national-specific (and international-specific) industry knowledge. Given the size, resources, and global changes in the economy, it makes sense to assume that there has been some pressure on audit firms to promote their national level expertise as opposed to local-office expertise.

The prior research on the direct impact of GFC on audit fees is rather limited and provides mixed results. A U.K. study by Hassan et al. (2014) shows that audit fees have increased in the five years following the mandatory adoption of IFRSs and as a result of the impact of the GFC, suggesting increased audit effort. Whilst studies on the impact of the GFC report higher audit fees during the GFC period in Australia (Xu et al., 2013) but lower audit fees in the U.S. during the same period (Krishnan and Zhang, 2013). None of these studies have examined how the auditor's industry specialisation may have changed over the years in terms of its impact on audit pricing. Furthermore, these studies have used shorter periods to investigate the association between audit pricing and the GFC, either during the GFC period (Krishnan and Zhang, 2013) or during the periods before and during the GFC (Xu et al., 2013). Therefore, our study, which covers the period 2004-2011, provides a more comprehensive analysis by 
covering the pre-GFC (2004-2006), during the GFC (2007-2008), and the post-GFC (2009-2011) periods in examining the auditor industry specialisation in the U.K. audit market.

\section{Auditor Industry Specialisation Research}

The empirical results of previous studies are somehow mixed regarding the impact of industry specialisation on audit fees. While many studies generally find a positive relation between auditor industry (national) specialisation and audit fees (e.g., Defond et al., 2000; Ferguson et al., 2003; Mayhew and Wilkins, 2003; Francis et al., 2005), many others provide somewhat different conclusions. For example, Carson and Fargher (2007) find the fee premium to occur only in the large client segment, whilst Casterella et al. (2004) reported fee premium in the small client market. Other studies provide marginal results or no relation at all (e.g., Palmrose, 1986; Pearson and Trompeter, 1994; Ferguson and Stokes, 2002; Basioudis and Francis, 2007); inconclusive evidence (Minutti-Meza, 2013), or even a negative relationship/fee discount (e.g., Ettredge and Greenberg, 1990). Overall, many researchers recognise that the results are often sensitive to the industry specialisation measures used, and to the country and the period analysed (Craswell et al., 1995; Ferguson and Stokes, 2002; Huang et al., 2007; Basioudis and Francis, 2007; Causholli et al., 2010; Hay and Jeter, 2011). Therefore, a range of sensitivity tests needs to be performed in order for the study's results to be adequately validated (Audousset-Coulier et. al., 2016).

In addition, the mixed results in prior research could also be explained by the type of strategy pursued by the industry specialist. While some industry specialist auditors pursue a product differentiation strategy by performing audits in a small proportion of clients in an industry at a premium fee to compensate for the higher audit quality offered, some other industry specialists may opt for a cost minimisation strategy by auditing a large proportion of clients, competing on price (either lowering audit fees or offering fee discounts) at the expense of audit quality (Cahan et al., 2011). It is also possible that the benefit from economies of scale from industry specialisation that are passed on by the auditor to the client take effect simultaneously such as when the audit fee premium for industry specialisation is smaller for auditors with a larger city-industry scale (Fung et al., 2012). Larger and less risky clients are also more attracted to purchase audit services from industry specialist auditors in order to fulfil their demand for higher audit quality, and whether a fee premium or fee discount results from the auditor client negotiations depends very much on the strength of the client's bargaining power (Casterella et al., 2004) and the perceived quality of the differentiated service (industry expertise) offered by the auditor (Hay and Jeter, 2011).

Since Francis et al. (1999) and Reynolds and Francis (2000), audit researchers have started examining other possible explanations for the above inconsistent results regarding the influence of industry specialisation on audit fees, and in essence, they have focused their attention from the audit firm (firm- 
wide phenomenon) to the specific audit office (office-level or city-level or local phenomenon). This stream of research argues that industry expertise is primarily developed through a specialisation at the local (city, office) level (Ferguson et al., 2003; Basioudis and Francis, 2007; Carson and Fargher, 2007; Hay and Jeter, 2011; Fung et al., 2012; Numan and Willekens, 2012; Minutti-Meza, 2013). Whether the audit pricing is dominated by firm-level or office-level industry expertise might explain the strength of knowledge sharing and transfer of industry expertise between the particular audit firm city-offices (Ferguson et al., 2003). For an audit firm to be priced on its national industry leadership, the market has to perceive that standardised level of audit quality exists across all of its national network offices so that the firm-level reputation for industry expertise (national industry leadership premium) can be widely earned and enjoyed irrespective of the audit office location (Vera-Munoz et al., 2006). On the contrary, if industry leadership premium only exists for city-specific industry leaders, this may show that industry expertise is a more local phenomenon and that it is closely tied to the audit professional staff who service clients in specific cities and industries (Basioudis and Francis, 2007).

As mentioned earlier, research using the national-city framework introduced by Ferguson et al. (2003) produces mixed results. In the U.S. and Australia, auditor's industry expertise based on joint national and office-level reputation matters more in the Big 4 audit market, as they are priced at a higher rate as compared to national industry leadership alone or city-specific industry leadership alone at an average premium of 18 percent and 24 percent respectively (Ferguson et al., 2003; Francis et al., 2005). While there is evidence of a significant fee premium for city-specific industry leadership alone in the U.S., industry leadership at the national or city level alone is not priced in the Australian market. On the contrary, recent evidence from New Zealand shows that industry specialisation premium for city leadership alone is higher than joint national-city leadership (Hay and Jeter, 2011). However, the similarity between these three countries is that national industry leadership alone is not priced in the audit market.

The prior U.K. evidence based on 2002-2003 data (Basioudis and Francis, 2007) stands in contrast to the U.S. and Australia, but similar to New Zealand by showing that the Big 4 city-specific industry leadership alone matters more than the joint national and city-specific industry leadership as it is able to earn higher fee premium (19 percent for city-specific industry leadership relative to 12 percent for joint national and city-specific industry leadership). Nevertheless, no explanation is provided as why this is the case. Also, no significant fee premium is reported for Big 4 national industry leaders relative to other Big 4 auditors that are not national industry leaders. The prior U.K. results imply that knowledge sharing and transfer in respect of industry expertise does not occur across the city-offices of the Big 4 firms in 2002-2003. 
In this paper, therefore, we examine whether the Big 4 national industry leadership and/or the cityspecific industry leadership commands audit fee premiums in the U.K. during the period 2004-2011, and we attempt to determine whether the findings of prior research are still valid, given the various regulatory intervention in the market for audit services in the recent years as well as the undoubted impact of the GFC.

\section{Sample, Data, and Audit Fee Model}

The sample comprises of all companies listed on the London Stock Exchange (LSE) between the financial years 2004 and 2011. We begin our sample in year 2004 so that we could compare our results with the prior U.K. study by Basioudis and Francis (2007) which was based on 2002-2003 data, as this enable us to examine the progression of the Big 4 industry specialisation strategy in the U.K. audit market. Data are collected from FAME ${ }^{4}$ and Thomson OneBanker databases. As the data on the location of the accounting firm's lead engagement office is not provided in any database, we had to manually collect this data from the office-specific letterhead of the audit report in the respective company's annual report in the sample. This data is then used to analyse the city-specific industry leadership, which is determined based on the accounting firm's share of aggregate industry audit fees for each unique city.

The initial sample comprises of approximately 22,217 companies listed on the LSE, which was screened to exclude companies that are not followed by FAME, are in the service providing sectors (i.e., financial services, public administration and defence, health and education, other services), and have got incomplete financial data ${ }^{5}$. This process results in a sample of 4,459 observations with complete audit fees data that is used to calculate the various auditor industry market shares. However, as this study is based on companies with Big 4 auditors only and aims to test if Big 4 industry leaders have a fee premium relative to other Big 4 firms who are non-leaders, we exclude the 1,688 non-Big 4 observations from the sample, resulting in 2,771 Big 4 observations only. A further 383 observations from the sample with less than two city-specific observations per industry are also excluded. This additional screening is performed as to ensure that the audit market in all cities in the sample is competitive where more than one audit client exists, although similar results would be obtained if the full sample of 2,771 observations is used. The final sample for this is study is 2,388 observations which represent 53.5 percent of the full sample with complete data on audit fees. The sample screening process for the final sample of 2,388 observations is summarised in Table 1.

\section{[INSERT TABLE 1 HERE]}

The industry classification used in this study is based on the FAME categorisation of the major industry sectors, where the numerous LSE industry codes (SIC codes) of similar industry nature are being categorised into only 13 major industry sectors. ${ }^{6}$ Further, this is the first study on auditor industry 
leadership that we are aware that uses data covering the pre-, during and post-GFC period. The use of three sub-samples would allow us to distinctively examine whether the Big 4 industry specialist auditors responded differently to the 2007/2008 GFC in terms of their pricing strategy and market share dominance.

Table 2 reports the sample distribution for the Big 4 audit firms in the pre-, during and post-GFC periods. Overall, it can be seen that the average audit fees has significantly increased from $£ 0.85$ million in the pre-GFC period to $£ 1.11$ million in the post-GFC period despite the decrease in the number of Big 4 audit clients from 1,063 in the pre-GFC period to 707 in the post-GFC period. The results of the independent $T$-tests indicate that there are significant differences in the average Big 4 audit fees ( $T$ statistic $=1.92, p<.10$ ) between the pre- and post-GFC periods. This supports the findings from a recent U.K. study by Hassan et al. (2014) and an Australian study by Xu et al. (2013) which both have also shown that audit fees are higher in the post-GFC period, suggesting that the Big 4 auditors responded to the GFC by charging higher audit fees to compensate for their increased audit effort.

Based on the $T$-test result ( $T$-statistic $=2.71, p<.01$ ), it can be observed that the average size of the Big 4 clients based on total assets is significantly smaller in the pre-GFC period ( $£ 2.4$ million) as compared to the post-GFC period ( $£ 4.2$ million) . There is no evidence of significant differences in the Big 4 average non-audit fees over the periods under examination. Within the Big 4 U.K. audit market, PwC is the leading audit firm with the highest number of clients and highest average audit fees, and there seems to be a significant increase in the average audit fees $(T$-statistic $=2.30, p<.05)$ and client's total assets (T-statistic $=2.76, p<.01$ ) of $\mathrm{PwC}$ in the post-GFC as compared to the pre-GFC period. Interestingly, Ernst \& Young is the audit firm with the lowest number of clients but has got a higher average audit and non-audit fees charged to its clients when compared with Deloitte and KPMG. Relative to other Big 4 firms, a significant drop in non-audit fees is only evident for KPMG in the postGFC period $(T$-statistic $=2.21, p<.05)$.

\section{[INSERT TABLE 2 HERE]}

Additional analysis of audit market concentration for the period 2004-2011 reveals that on average 44 percent of companies from our sample are audited by London offices of the Big 4 firms, and paid an annual average 82 percent of the sample audit fees. Similarly, 33 percent of the companies in the sample are headquartered in London, with only 53 percent of them are audited in London itself. Similar to Basioudis and Francis (2007), it seems that the audit market in the U.K. continues to be dominated by London. ${ }^{7}$ Given the smaller geographical size of the U.K. relative to countries like the U.S. and Australia, and the position of London as the primary commercial centre, it may seem logical to assume that industry expertise in the U.K. may more likely to be driven by the firm's total client base (national clientele) rather than city-specific expertise based on office-specific clienteles. 
Our primary analysis is based on all companies in the sample with Big 4 auditors and tests if Big 4 industry leaders have a fee premium relative to other Big 4 non-leaders. The reduced sample of 2,388 observations for the Big 4 industry leadership test comprises of on average 24 unique cities and 72 unique city-industry combinations per year over the period examined. The average of four observations per city-industry combination is similar to Basioudis and Francis (2007).

In order to apply the national-city framework developed by Ferguson et al. (2003) to our analysis, we have partitioned the Big 4 industry specialist auditor observations into the following variables specification:

(1) indicator variable $N A T, 1=$ companies audited by the Big 4 national industry leaders $(N=830)$, $0=$ otherwise;

(2) indicator variable $C I T Y, 1=$ companies audited by the Big 4 city-specific industry leaders $(N=$ 1,085), 0 = otherwise;

(3) indicator variable JOINT, 1 = companies audited by auditors that are joint (both) the national industry leader and the city-specific industry leader $(N=657), 0=$ otherwise;

(4) indicator variable $C I T Y \_O N L Y, 1=$ companies audited by the city-specific industry leader alone, without also being the national industry leader $(N=428), 0=$ otherwise;

(5) indicator variable $N A T \_O N L Y, 1=$ companies audited by the national industry leader alone, without also being the city-specific industry leader $(N=173), 0=$ otherwise.

The last three indicator variables above are used to control explicitly for the joint effect of national and city-specific industry leadership, which is the primary focus of the analysis.

In other words, companies with auditors that are national industry leaders $N A T(N=830)$ can be decomposed into those audited by national leaders alone $N A T \_O N L Y(N=173)$, plus those whose auditors are joint national and city-specific industry leaders JOINT $(N=657)$. Similarly, companies with auditors that are city-specific industry leaders $\operatorname{CITY}(N=1,085)$ can be decomposed into those audited by city-specific industry leaders alone CITY_ONLY $(N=428)$, plus those auditors that are jointly national and city-specific industry leaders $\operatorname{JOINT}(N=657)$. The purpose of these three partitions is to test for the separate effects of national and city-specific industry leadership, as well as to isolate the joint effect of national and city-specific industry leadership on audit pricing.

Descriptive statistics are reported in Table 3 for the full Big 4 sample $(N=2,388)$, the clients of the Big 4 joint national and city-specific industry leaders $\operatorname{JOINT}(N=657)$, the Big 4 city-specific industry leaders but not national industry leaders CITY_ONLY $(N=428)$, and clients of the Big 4 national industry leaders but not city-specific industry leaders $N A T \_O N L Y(N=173)$. Comparing between the different samples, clients of the Big 4 joint national and city-specific industry leaders (JOINT) are 
slightly larger in size (LTA), have higher audit complexity (SQRTSUBS), pay relatively higher audit fees $(L A F)$, are more profitable $(R O I)$, have lower liquidity risk $(Q U I C K)$ and higher leverage $(D E)$. The clients of the Big 4 city-specific industry leaders but not national industry leaders (CITY_ONLY) make more losses (LOSS) compared to the other Big 4 industry leaders. Whereas the clients of the Big 4 national industry leaders but not city-specific industry leaders $\left(N A T_{-} O N L Y\right)$ receive fewer modified audit reports $(O P I N I O N)$, pay relatively higher non-audit fees $(L N A F)$, have higher audit risk $(C A T A)$ and lower initial audit engagements (INITIAL). The remaining variables (LONDON, CATA, FOREIGN, $B U S Y, I N I T I A L)$ are comparable across the specialty auditor groups. An independent sample $t$-test indicates there is no significant difference between the mean of $L A F$ for the Big 4 city-industry leaders only and the Big 4 national industry leaders only $(F$-statistic $=0.87, p>.10)$.

\section{[INSERT TABLE 3 HERE]}

Table 4 presents the correlation matrix for all the variables examined in the study. The variable JOINT is highly correlated with NAT and CITY at 0.84 and 0.67 respectively, which is expected as JOINT is the interactive effect between NAT and CITY variables. Correlations between the dependent and the independent variables are as expected and no correlations above 0.70 are present among the control variables.

\section{[INSERT TABLE 4 HERE]}

\section{Audit Fee Model}

We adopt the same audit fee model as used in previous studies (for example, Basioudis and Francis, 2007; Francis et al., 2005) to estimate the audit fee premium for industry leadership, as this model has a strong explanatory power and has been proven to be robust across different samples, countries and time periods. The audit fee model is estimated as the industry fixed-effects and year fixed-effects model to control for systematic differences in fees across the 13 industries and eight years period examined in the sample. An industry fixed-effects model controls for potential omitted variables in case there are any systematic differences across industries and years with respect to client's company size, risk or audit complexity that are associated to audit fees (Basioudis and Francis, 2007). We specify the ordinary least-squares (OLS) regression model as follows:

$$
\begin{aligned}
\mathrm{LAF}= & \alpha+\beta_{1} \mathrm{LTA}+\beta_{2} \mathrm{SQRTSUBS}+\beta_{3} \mathrm{CATA}+\beta_{4} \mathrm{QUICK}+\beta_{5} \mathrm{DE}+\beta_{6} \mathrm{ROI} \\
& +\beta_{7} \text { FOREIGN }+\beta_{8} \text { OPINION }+\beta_{9} \text { BUSY }+\beta_{10} \mathrm{LOSS}+\beta_{11} \mathrm{LNAF} \\
& +\beta_{12} \mathrm{LONDON}+\beta_{13} \text { INITIAL }+\beta_{14} \text { AUDITOR }+\varepsilon
\end{aligned}
$$

where:

LAF $\quad$ natural log of audit fees in GBP'000;

LTA = natural log of total assets in GBP'000; 


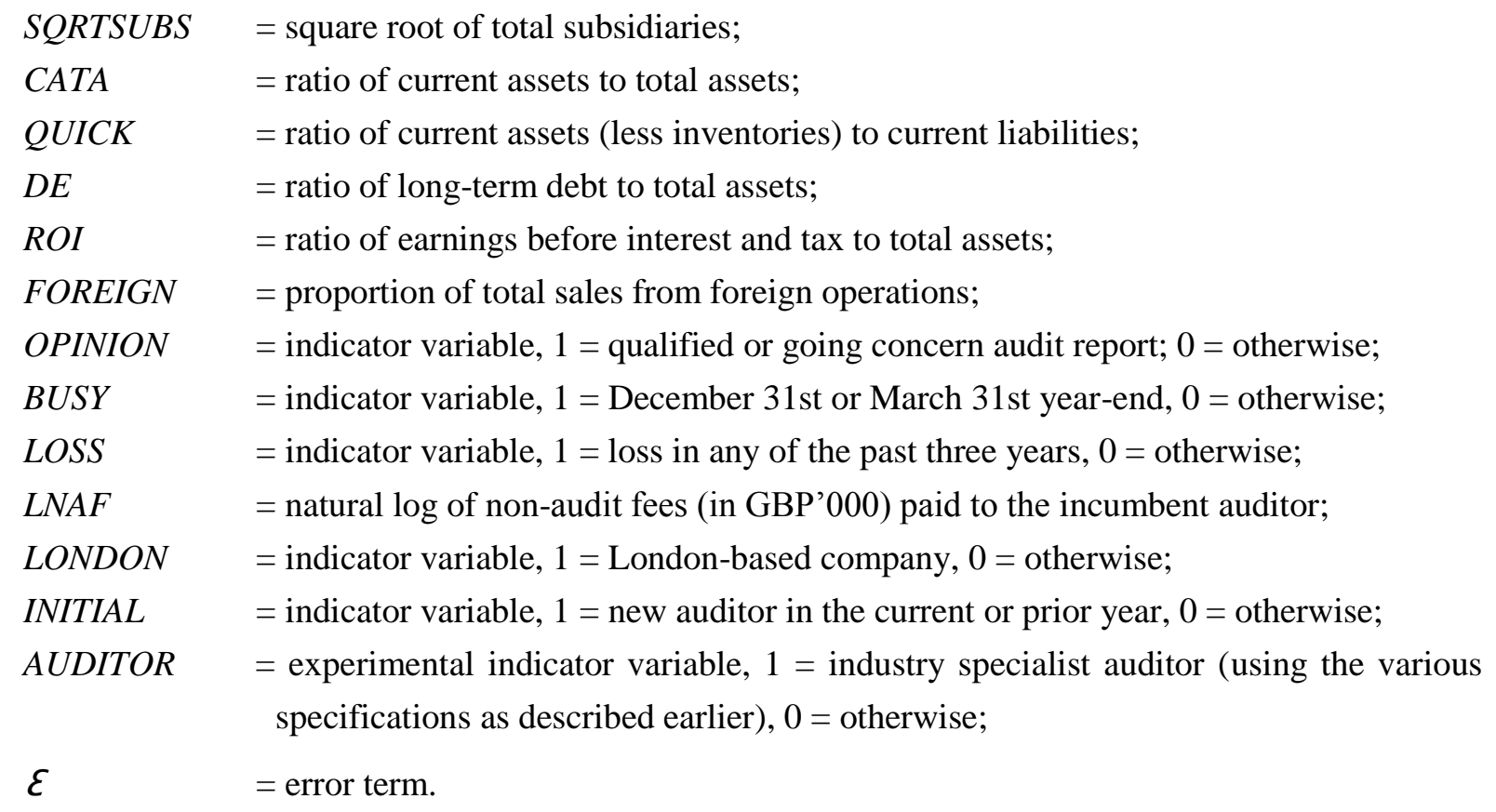

The 13 control variables used in the model above are the standard audit fee control variables used in the audit fee models in previous studies. Consistent with prior research (Whisenant et al., 2003; Francis et al., 2005; Basioudis and Francis, 2007; Choi et al., 2010), higher fees are expected for large size clients (LTA), for clients with greater audit complexity (SQRTSUBS and FOREIGN) and greater audit risk (CATA, DE, and LOSS), for London-based companies (LONDON) due to higher living costs experienced in London, for modified audit reports (OPINION) due to more investigative efforts in such circumstances, when the incumbent external auditor provides non-audit services to the client (LNAF), and during the busy seasons (BUSY) for the auditor. Lower fees are expected for higher values of the risk variables $Q U I C K$ and $R O I$, as clients with a larger $Q U I C K$ ratio are less risky (and more liquid) and, therefore, expected to have smaller audit fees. More profitable clients (with higher ROI) pose less risk to the auditor, resulting also in lower fees. Also, lower fees are expected due to lowballing effects if an audit represents the first or second year of engagement (INITIAL). Finally, the coefficient of the AUDITOR variable represents the magnitude of the fee premium under different definitions of industry specialist auditor as explained earlier and is further explained in the next section. 


\section{National and City-Specific Industry Leadership Tests}

The sample comprises 2,388 observations over the period 2004-2011 and three models test if Big 4 industry leaders (defined in various ways) have higher fees than other Big 4 auditors in a period of major regulatory interventions and changing economic conditions. The models are estimated using the three specifications as used in Ferguson et al. (2003). Model 1 tests the effect of national-level industry leadership per se (NAT) on differential Big 4 audit pricing for $N=830$ observations in which the Big 4 auditor is the national industry leader, and the default comparison group is all of the remaining 1,558 observations not having Big 4 national industry leaders. Model 2 tests the effect of city-specific leadership per se (CITY) for $N=1,085$ observations in which the Big 4 auditor is the city-specific industry leader, and the default comparison group is the remaining 1,303 observations not audited by city-specific industry leaders.

Relatively to Model 1 and Model 2, Model 3 is the primary model of interest because it controls explicitly for the joint effect of national and city-specific industry leadership through the use of three auditor indicator variables, that is: Big 4 auditors that are jointly national and city-specific industry leaders $\operatorname{JOINT}(N=657)$; Big 4 auditors that are city-specific industry leaders but are not national industry leaders CITY_ONLY $(N=428)$; and Big 4 auditors that are national industry leaders but are not city-specific industry leaders NAT_ONLY $(N=173)$. The default comparison group is the Big 4 auditors that are neither national nor city-specific industry leaders $(N=1,130)$.

\section{[INSERT TABLE 5 HERE]}

Results of the three model estimations are reported in Table 5. Significance levels for model coefficients are reported as two-tailed $p$-values. All models are significant at $p<.0001$ with adjusted $R$-squares of around 86 percent. Except for $D E$, all control variables are significant at $p<.01$ and in the expected direction, while the variables, OPINION and INITIAL, are insignificant at $p>.10$.

Model 1 tests the effect of the national industry leadership on audit pricing, without controlling for the joint national and city-specific industry leadership, and the auditor indicator variable $N A T$ is found to be positive and significant $(p<.01)$. The coefficient value is 0.055 which equates to an average audit fee premium of 5.65 percent. ${ }^{8}$ This result is in contrast to the only previous U.K. study by Basioudis and Francis (2007) where no significant audit fee premium for Big 4 national industry leadership is documented for the top-ranked national industry leader, but provides an important indication that the national-specific industry expertise has gained significant investment in the period under examination. Model 2 tests the effect of city-specific industry leadership on audit pricing, without controlling for the joint national and city-specific industry leadership effect. The auditor indicator variable CITY is positive and significant $(p<.01)$. The coefficient value is 0.039 which equates to an average audit fee premium 
of 3.98 percent. ${ }^{9}$ This fee premium is three times lower as compared to prior U.K. finding by Basioudis and Francis (2007) of 16 percent. This result confirms the restructuring of the industry specialisation that has happened in the U.K. since 2002 by diminishing the focus on the city specialisation and perhaps refocusing on the national industry specialisation. ${ }^{10}$

Interestingly, Model 3, which is the model of interest and controls for the joint effect of national and city-specific industry leadership shows that neither the national industry leadership alone (NAT_ONLY) nor the city-specific industry leadership alone $\left(C I T Y_{-} O N L Y\right)$ results in a significant fee premium $(p>$ .10). Instead, a fee premium for industry leadership is only earned by the city-specific industry leaders if and when they are also national industry leaders. The coefficient for the joint national and city-specific industry leadership $(J O I N T)$ is $0.069(p<.01)$ which represents a premium of 7.14 percent.

The above findings differ somehow from Basioudis and Francis (2007) who report a larger and significant fee premium when the auditor is a city-specific industry leader alone (19 percent) compared to when the auditor is a joint national and city-specific industry leader (12 percent). In contrast, our overall results for the full period of 2004-2011 indicate that the premium for industry leadership in the U.K. is no longer driven by the office-level industry expertise as shown previously in Basioudis and Francis (2007) using 2002-2003 data. Our U.K. evidence of fee premium for industry leadership is also in contrast to the U.S. where a significant premium is documented for both the joint national and city leadership as well as the city-specific industry leadership alone (Francis et al., 2005). Also, the evidence presented in this paper stands in contrast to New Zealand where city-specific industry leadership plays a more important role than joint national and city industry leadership (Hay and Jeter, 2011). Instead, this new U.K. evidence is rather similar to Australia (Ferguson et al., 2003) where a fee premium only exists for the joint national and city-specific industry leaders (despite being comparably lower in the UK at 7.14 per cent versus 24 per cent in Australia). Office-level industry expertise seems to play a more important role in Australia as the national leadership rankings are driven by the specific offices where the audit firms are city leaders. However, it seems that this is not the case in the U.K. where national industry leadership appears to play a more important role, based on the evidence of a marginally higher fee premium for national industry leaders per se (5.65 percent as reported in Model 1) relative to city-specific industry leaders per se (3.98 percent as reported in Model 2).

This new evidence from the U.K. implies that the Big 4 auditor industry specialisation at the national (firm-wide) level and city-specific (office) level both have simultaneously an impact on audit pricing, and therefore, neither perception alone should be considered sufficient in explaining the existence and magnitude of a fee premium for industry expertise. The new evidence also implies that market shares and industry specialisation are evolving replacing old ones in order for the audit firms to compete more effectively and efficiently. ${ }^{11}$ It also confirms the initial intuition discussed earlier in the paper that the 
various changes in regulations and technology, the GFC, and national and worldwide integration of markets and competition have influenced the specialisation strategies of the audit firms from the cityspecific industry expertise to the national-specific industry expertise. Overall, our results shed further light to auditor industry leadership phenomenon in the U.K. by documenting evidence of knowledge sharing across the Big 4 city offices, which was not prevalent in the beginning of the 21 st century.

\section{Test on the Effect of Financial Crisis on Auditor Industry Specialisation}

In this section, we examined whether the GFC have had a direct effect on the fee premium on the Big 4 industry leaders. Results of the analysis are presented in Table 6 . The same regression analysis is run for the pre-, during and post-GFC periods separately to determine whether there is any differential effects on the documented fee premium earned by the Big 4 industry leaders relative to the other Big 4 non-leaders. The full Big 4 sample $(N=2,388)$ is partitioned into the pre-GFC period of 2004-2006 ( $N$ $=1,063)$, the GFC period of 2007-2008 $(N=618)$, and the post-GFC period of 2009-2011 $(N=707)$. All the regressions are valid with $R$-squares between 85.3 and 88.1 percent.

Results for the pre-GFC period seem to be consistent with the results in the post-GFC period, where significant fee premium is reported for the national industry leader (NAT) and city-specific industry leader (CITY) respectively in Model 1 and Model 2. Also, in Model 3, only the joint national and cityspecific industry leaders (JOINT) earn fee premiums, but no evidence of the city specific industry leaders alone (CITY_ONLY) or the national industry leaders alone (NAT_ONLY) being able to charge fee premiums. Taken together, the findings from the pre- and post-GFC periods are consistent with the main findings reported in Table 5 earlier. Nevertheless, the coefficient for the fee premiums seems to be higher in the post-GFC period as compared to the pre-GFC period across all the three regression models examined.

On the other hand, during the GFC period of 2007-2008, it can be seen that there is no evidence of a significant fee premium for auditor industry leadership either at the national or city-specific industry level (the JOINT coefficient is slightly significant at one-tail, $p<.10$ ). This finding suggests that the financial crisis did have an effect on the auditor industry specialisation strategy or fee premium. The finding is interesting as it indicates that the audit firms were careful in upsetting the market further given they were partially blamed for the GFC.

Alternatively, we have also run the regression analysis using year dummies for the GFC and post-GFC periods and using the total sample of 2,388 companies for the whole period 2004-2011, and the findings (not tabulated) seem consistent with the main findings in Table 5 earlier. In addition, the year period dummies are positive and significant suggesting an increase in audit fees during the GFC and post-GFC periods. 


\section{[INSERT TABLE 6 HERE]}

We have further analysed the average market shares of the industry specialist auditors in the pre-, during and post-GFC periods respectively. The (untabulated) analysis shows that the average market share of the national industry leaders (NAT) has significantly increased from 47 percent in the pre-GFC period to 60 percent in the post-GFC period $(T$-statistic $=12.65, p<.01)$. This confirms our earlier suggestion that emphasis has been placed on the national-specific industry expertise during the period under examination, which implies that the sharing and transferability of industry expertise knowledge and skills between the city offices of the Big 4 audit firms has increased over the recent years.

At the city-industry level, the average market share of the city-specific industry leaders (CITY) seems to have decreased considerably during the GFC period of 2007/2008 to 63 percent from 67 percent in the pre-GFC period before starting to go up again in the post-GFC period to 69 percent. However, based on the $T$-test result, there seems to be no significant differences in the average market share of the cityspecific industry leaders between the pre-and post-GFC periods $(T$-statistic $=1.42, p>.10)$.

Finally, it is worth mentioning that the average number of city-industry combinations has dropped from 79 in the pre financial crisis period, to 72 during the financial crisis period and subsequently to 64 in the post financial crisis period. There are three possible explanations for the continuing decrease in the average number of city-industry combinations, either 1) there is lesser number of Big 4 audit offices operating in different cities, or 2) there is lesser number of industries in which the individual Big 4 city offices choose to specialise, or finally 3 ) both of the above are present simultaneously. These interpretations can also be read in conjunction with the fact that a large number of listed companies were delisted from the LSE during and after the GFC.

\section{Sensitivity and Robustness Tests}

Alternative industry classification scheme as per Basioudis and Francis (2007)

Basioudis and Francis (2007) categorised the industries based on LSE's two-digit SIC codes. To check whether our results are robust across a different industry classification scheme, we reclassified our sample into 25 industry categories, based on the LSE two-digit SIC codes and as used in Basioudis and Francis (2007), and re-performed the same analysis as in Table 5. Under the two-digit SIC Codes industry classification, there are $N=880$ companies with Big 4 auditors who are national industry leaders $N A T$, which can be decomposed into those audited by Big 4 national leaders alone NAT_ONLY $(N=548)$, plus those whose Big 4 auditors who are joint national and city-specific industry leaders $\operatorname{JOINT}(N=332)$. While there are $N=616$ companies with Big 4 auditors who are city-specific industry leaders CITY that can be decomposed into those audited by city-specific industry leaders alone 
CITY_ONLY $(N=284)$, plus those Big 4 auditors that are jointly national and city-specific industry leaders $\operatorname{JOINT}(N=332)$.

In untabulated results, we obtain qualitatively similar results in Model 3 as reported earlier in Table 5, where the industry leadership coefficient is only significant for the Big 4 joint national and city leaders JOINT (averages at 7.90 percent). While the fee premiums for national industry leaders NAT in Model 1 and city-specific industry leaders $C I T Y$ in Model 2 are comparable at 3.46 percent and 3.98 percent respectively.

Next, we partition the results into yearly regression to examine the stability of the measures during the period examined and explain why our results are different from the previous U.K. study by Basioudis and Francis (2007). Again, unreported evidence shows that the results for the year 2004 (which is the first year of analysis after the Basioudis and Francis (2007) study) seem to be very similar to this prior study, except that the coefficient for the Big 4 joint national and city leaders (JOINT) in Model 3 is only significant at one-tailed test.

For the years 2005-2011, the results start showing different patterns per individual year. There is no evidence of a fee premium at all in year 2005, followed by evidence of fee discount (one-tailed test) in year 2006 provided by the Big 4 city-specific industry leader alone (CITY_ONLY). In year 2007, the Big 4 national industry leadership (NAT) becomes dominant as the variable is significant in Model 1 and the Big 4 national industry leader alone (NAT_ONLY) variable in Model 3 is also significant (onetailed test). The city-specific industry premium documented earlier in Basioudis and Francis (2007) seems to be diminishing slowly, as there is still a slightly significant coefficient in 2004 and then it is completely wiped out in the following few years (at the $1 \%$ level of significance) until it appears again in year 2008.From the year 2008 onwards, both the Big 4 city-specific industry leader (CITY) in Model 2 and the Big 4 joint national and city leader (JOINT) in Model 3 are significant (one-tailed test), and the Big 4 national industry leader (NAT) variable also becomes significant in years 2010 and 2011 (with higher coefficients than the Big 4 city-specific industry leader CITY).

The significant diverse findings obtained when the 2004-2011 full sample is partitioned across different sample years suggest that statistical evidence obtained from a sample of one single year can be perhaps misleading and risky to be used for generalisation purposes (Audousset-Coulier et al., 2016).

\section{Alternative regression estimator}

While the OLS regression estimators with White (1980) robust standard errors are consistent in the presence of heteroscedasticity, it has been argued that its standard errors could be biased or produce mis-specified test-statistics (either over- or under-estimating the true variability of the coefficient 
estimates) when either time series or cross sectional dependence is present (Gow et al., 2010, p. 487; Petersen, 2009). Thus, we have re-estimated all the main regression models in Table 5 using cluster robust standard error which cluster for firm dimension. The test results (not tabulated) provide qualitatively similar findings as reported in the main regression analyses in Table 5.

\section{Individual auditors and industries}

We also test whether results reported in Table 5 are driven by individual Big 4 audit firms or individual industries. Following Francis et al. (2005), first, we re-estimated all the models in Table 5 by dropping each of the Big 4 audit firms. Next, we re-estimated the models by dropping each of the 13 industries. The findings (not tabulated) are qualitatively the same as in Table 5, which indicates that the Big 4 firms and individual industries do not drive the results.

\section{Eliminate the effect of monopoly pricing in the market of city-specific industries}

Our sample screening process stipulates a minimum of two observations per unique city-industry combination as to ensure that there is a competitive audit market in presence $(N=2,388)$. However, a city-specific industry may still be uncompetitive if all the companies in that particular industry in that particular city are audited by the same auditor, as this indicates monopoly pricing by a single auditor. Hence, in order to eliminate such effect from our main results, we delete a further 89 observations from 36 city-industry combinations, which reduces the sample size to 2,299 observations. As shown in Table 7 , the results are qualitatively the same as in Table 5 when re-estimated on this reduced sample.

\section{Alternative definition of auditor industry leadership}

We further test whether our results are robust to alternative different definitions of auditor industry leadership found in prior studies. First, we adopt the alternative market share cut-off approach introduced by Neal and Riley (2004) to define the Big 4 industry specialists. In order to apply Neal and Riley's formula to the city level, we follow Reichelt and Wang (2010) approach where rather than using the number of Big $\mathrm{N}$ auditors, we use the average number of auditors per city-industry combination. This is because there are fewer auditors in a city-industry combination and non-Big $\mathrm{N}$ firms can also be specialists at the city level. On average, there are 2.5 auditors per city industry market, which computes to 48 percent $(1.2 \times 1 / 2.5)$, or approximately 50 percent. Thus, using this approach, a national (city) industry specialist is designated to the audit firms where the auditor has a market share greater than 30 percent (50 percent) in a particular industry, within a particular year and city. As the approach requires a minimum 30 percent market share for national industry specialists, this allows for multiple auditors to be named national industry specialists. On the other hand, it reduces the number of city-specialists only to those with a market share exceeding 50 percent, and this is often the case as there is absence of 
single industry specialist in larger cities like London, Birmingham, Manchester and Leeds as there is not normally one Big 4 firms domineering in those markets. As shown in Table 7, the results using this alternative market share cut-off is comparable to the main findings reported earlier in Table 5.

In addition, we also adopt the portfolio approach (Neal and Riley, 2004) as an alternative measure of auditor industry leadership. Portfolio approach is different from the market share approach where an audit firm is still considered an industry leader in those industries in which they generate the most revenue and presumably have invested the most resources into developing industry-specific knowledge, even if they do not maintain a leading market share in that industry (Neal and Riley, 2004). Under the portfolio approach, we use continuous measure of industry leadership and rerun the regressions for Model 1 and Model 2 to test the Big 4 national industry leadership and Big 4 city-specific industry leadership separately. In Model 3, we include both the national industry leadership test variable and the city-specific industry leadership test variables together in a single model. Based on the untabulated results, in Model 1, we find that the Big 4 national industry leader variable is significant at $p<.10$ (coefficient $=0.116$ ). In Model 2 the coefficient for city-specific industry leadership variable is not significant $(p>.10)$. Whereas in Model 3, we find that the national industry leadership variable is significant (coefficient $=0.127, p<.05$ ) but the city-specific industry leadership variable is not significant $(p>.10)$.

Both the results using the alternatives definition of auditor industry leadership in this section support our argument and findings in the main analysis earlier that the national industry leadership has gained more importance relative to city-specific industry leadership in the post-SOX period in the U.K.

\section{Effect of potential nonlinearities on company size and audit fees}

We further address the concern that non-linearities and misspecification of company size may drive the main results in Table 5. We estimate a regression model here in which the dependent variable is based on ranked values of $L A F$ and which may be less sensitive to potential non-linearities than continuous values of $L A F$. In a second regression model, we rank both the dependent variable $(L A F)$ and the size variable (LTA) to further mitigate the effects of potential non-linearities between audit fees and company size. These two analyses affirm that the joint national and city-specific industry leadership (JOINT) results in the highest fee premium and that there is neither a fee premium for national industry leadership alone (NAT_ONLY) nor city-specific industry leadership alone (CITY_ONLY), as in Table 5. Hence, we conclude that there is no reason to believe that model misspecification or non-linearities with respect to company size explain the results in Table 5.

Auditor industry leadership market share based on clients' total assets and total sales 
We further test whether the main findings reported in Table 5 are sensitive to the use of audit fees to measure auditor market shares and industry leadership. The market shares of audit firms are recalculated based on the clients' total assets and on clients' total sales, and the results are presented in Table 7. The empirical evidence based on these two alternative market share measures suggests that the fee premium for national industry leaders $(N A T)$ in Model 1 remains significant. However, there is no evidence of fee premium $(p>.10)$ attached to city-specific industry leaders (CITY) in Model 2, and so this is different from the main results in Table 5. In Model 3, we can see that there are still premiums for the joint national and city-specific industry leaders (JOINT), but it is interesting that a fee discount is reported for the first time for the city-specific industry leaders alone CITY_ONLY $(p<.01)$. The fee premium for the joint leaders is lower in the analysis here from all other previous analyses, and possibly the discount offered by the city-specific industry leaders alone offsets the higher fee premium charged by the joint leaders.

\section{Sub-samples based on auditee size, risk and growth}

To confirm whether the earlier documented results in Table 5 for the Big 4 sample are robust across different sample characteristics, we rerun the same analysis on various sub-samples based on client's size, risk and growth categorisation. The coefficients and the significance level for these tests are reported in Table 7.

To examine the Big 4 industry leadership premium based on the auditee size, we follow Francis et al. (2005) by splitting the Big 4 sample $(N=2,388)$ into two equal sub-samples based on the median absolute value for total assets of GBP£241.9 million. The large client segment and small client segment each has $N=1,194$ observations respectively. The evidence of fee premium for both the large and small client segments are consistent with the main findings in Table 5, with higher fee premium reported for the large relative to small clients of the Big 4 audit market.

To examine whether there are differentiated premiums for industry expertise between the high risk and low risk auditor clients, we follow prior research on auditor independence (Geiger and Raghunandan 2001, Geiger and Rama 2003; Basioudis et al., 2008), and define risk as the probability of client being financially distressed. We determine a financial distress company using the probability of bankruptcy model introduced by Hopwood et al. (1994) and modified by Geiger and Raghunandan $(2001)^{12}$. The Big 4 sample is equally divided into a sub-sample of high risk and low risk clients $(N=1,194$ respectively) based on the median value of the probability of bankruptcy score which is 0.49 . As shown in Table 7, the audit fee premium for national industry leadership (NAT) is higher for high risk clients while the premium for city-specific industry leadership (CITY) is higher for low risk client. Both in the high risk and low risk client's segments, we find that the premium for joint national and city-specific industry leader (JOINT) is comparable between the large and small client, while there are no fee 
premiums reported for national industry leader alone (NAT_ONLY) and city-specific industry leader alone (CITY_ONLY), as in Table 5.

Finally, using the market to book ratio as the proxy of auditor client's growth (Carcello and Nagy, 2004), we split our Big 4 sample into a sub-sample of high growth and low growth clients $(N=1,194$ respectively) based on the median value of the market to book ratio for the Big 4 sample (0.89). As shown in Table 7, the fee premiums for city-specific industry leadership (CITY) and joint national and city-specific industry leadership (JOINT) are higher for low growth clients as compared to high growth clients. The fee premium for national industry leadership (NAT) is comparable between the high and low growth companies. These results are comparable to our main results in Table 5 .

\section{[INSERT TABLE 7 HERE]}

National industry leader (NIL) vs. non-leader (non-NIL)

In this paper, a shift of auditor's specialisation towards expertise at the national level has been proposed, and the results obtained so far are in the direction of supporting this argument. In other words, the findings of the paper lead to the conclusion that a fee premium for industry leadership is only earned by the city-specific industry leaders if and when they are also national industry leaders.

In this part of the paper, we refine the main test of the study and examine whether the Big 4 national industry leaders $(N I L)$ are able to charge directly higher prices against the Big 4 non-leaders (non-NIL). We have used a matched-pair design for the analysis in this subsection here in order to better support the previously documented effect in this paper of the Big 4 national industry leadership. After having identified 830 companies that are audited by the Big 4 national industry leaders in the period 20042011, we treat this sample as the test sample (i.e., the NIL sample). We then matched these 830 Big 4 NIL clients with those audited by a Big 4 firm who is a non-leader in the same industry. The matching to our test sample companies is based on size (net sales and/or total assets), major industry, and year, in the order mentioned. These 830 matched companies audited by national industry non-leaders comprise our control sample (i.e., the non-NIL sample). We have performed our analyses on the 830 companies with NILs and the matched 830 companies with non-NILs. This procedure ensured that we included similar companies with respect to company size, type of industry, and year in our experimental and control samples for analysis. It also provides direct support towards the effect of Big 4 industry expertise at national level.

The model coefficient results (untabulated) for the variable of interest indicate that the magnitude of national industry leader variable $(N A T)$ is significantly positively associated $(p<.01)$ with audit pricing for the full sample, and the pre- and post-GFC periods. During the GFC period, the results are weakly 
positive and significant ( $p=0.088$, one-tail), indicating some diminishing premiums in this period. Overall, our regression results suggest that companies audited by Big 4 national industry leaders (NILs) pay higher amounts of audit fees than companies audited by Big 4 non-leaders (non-NILs). We can conclude, therefore, that the trend of the results observed in this sensitivity analysis section is also observed here in this more refined analysis. In other words, the test results here confirm the significance of the Big 4 national industry expertise in the period 2004-2011 in the U.K.

\section{Summary}

On the whole, the sensitivity tests above provide strong evidence of a fee premium for Big 4 firms who are joint national and city-specific industry leaders in the U.K. in the period 2004-2011. This fee premium appears clearly to be driven by the national industry leaders and is consistently significant when tested using alternative industry classification scheme, alternative definition of auditor industry leadership, dropping uncompetitive audit markets, in different sub-samples based on the client's size, risk and growth categorisation, and when using total assets and total sales as alternative measures of market shares. National industry leadership alone and city-specific industry leadership alone do not result in any fee premium, with the exception for the small client segment, where there is evidence of a significant fee premium for city-specific industry leadership alone. Based on the findings of this study, there is, it seems, a clear progression from Big 4 city-specific industry expertise to Big 4 nationalspecific expertise in the U.K.

\section{Discussion and Conclusion}

In an increasingly competitive market, audit service provision and development has to be continuous to ensure services meet the ever-demanding needs of regulators and stakeholders. Furthermore, in a period of significant regulatory initiatives and declining financial conditions due to GFC, someone would expect to see a major effort by audit firms to develop a thorough understanding of these and other emerging drivers of change. Hence, it is expected that audit firms may have been forced to consider their business strategies, business models and operating structures (Firth, 2002, Srinidhi and Gul, 2007), and may have modified their industry specialisation strategies. In essence, it is expected that the audit firms may have reengineered their activities in order to be able to provide more effective audit services and increase the confidence in the auditors' performance. Effectively, audit firms may have invested into shifting gradually their focus and specialisation from the city-level to national level, in order to be able to survive in the highly competitive and concentrated market for audit services.

The purpose of this study is to investigate the effect of Big 4 industry specialisation on the pricing of audit services in the U.K. in a period of various regulatory interventions and declining economic conditions due to GFC. We have used a sample from the U.K. for the period 2004-2011, and the 
empirical evidence indicates that the audit fee premium for the Big 4 industry leadership is only earned by the city-specific industry leaders if and when they are also national industry leaders, and that neither the national industry leader alone nor the city-specific industry leader alone is priced anymore in the U.K. audit market during the period under investigation. Our findings are also robust to alternative industry classification scheme, alternative definition of auditor industry leadership, dropping uncompetitive audit markets, in different sub-samples based on the client's size, risk and growth categorisation, and when using total assets and total sales as alternative measures of market shares.

Further, given the various regulatory developments in the first decade of this century, the corresponding changes in the audit environment, and the effect of the GFC on the specialisation strategies of audit firms, our study has also examined the response of the Big 4 industry specialist auditors to the GFC as compared to the pre- and post-GFC periods. Hence, our study has seeked to test whether different conclusions can be drawn in the period after the GFC (i.e., the period 2009-2011) as compared to the U.K. evidence in prior periods. When the sample is split into three sub-periods (the pre-GFC, during the GFC and the post-GFC period), the empirical results confirm the main results of the study that the Big 4 audit firms are able to collect audit fee premiums when they are only designated as joint national and city-specific industry leaders across all three sub-periods. The fee premiums seem to be larger in the GFC period and in the post-GFC period, as compared to the pre-GFC period.

The study's results imply that auditor industry leadership at the national (firm-wide) level and cityspecific (office) level both have an impact on audit pricing in the U.K in 2004-2011, suggesting that market shares and industry specialties are evolving replacing old ones in order for the audit firms to compete more effectively and efficiently. It appears, therefore, that the Big 4 audit firms have revised their industry specialisation strategies by focusing on establishing firm-wide reputations for industry expertise relative to office-level industry expertise that was documented in the earlier study of Basioudis and Francis (2007). From the demand side of the market, this shows that the U.K. market now perceives the Big 4 industry expertise is only credible when the auditor is jointly the national industry leader and the city-specific industry leader, and that this credibility is valued and priced in the audit market relative to national or city-specific industry leadership alone.

This study has several implications for regulators and investors. Research on fee premium for auditor industry specialisation, particularly using the national-city framework, provides an indication on how widely industry expertise has been distributed within the Big 4 audit firms at the national and city level. Such research informs the regulators and investors on the effectiveness of the auditor industry specialisation strategy and the differential effect of industry expertise (firm wide and office-specific) on auditor's remuneration. Also, empirical evidence from another country is helpful in determining if 
the city versus national framework is pertinent to understanding Big 4 reputations and if this framework may have changed due to the regulatory changes and the impact of the GFC.

Given that there is absence of a study that examines the impact of these recent period developments on the Big 4 differentiation strategy through industry specialisation, our study contributes to the understanding of how the regulatory changes and the impact of the GFC may have affected the pricing of audit services provided by industry specialists. Furthermore, given that our study in the U.K. has documented different findings compared to the evidence at the beginning of the century, it may be worthwhile for similar studies to be carried out in other countries using data from the period affected by the GFC to see whether the findings reported earlier in those countries still hold, whether audit firm specialisations last over time and whether audit fee premiums are allocated to different specialisation over time.

Besides that, whether national and/or city-specific dimensions of auditor industry expertise have a differential effect on corporate earnings quality has yet to be empirically examined in the U.K. This research question is important given that evidence from the U.S. shows that clients of the Big 4 firms who are joint national and city-specific industry leaders have lower discretionary accruals, lower likelihood of meeting or beating analysts' earnings forecasts by one cent per share and higher likelihood of being issued a going-concern audit opinion as compared to clients of national industry leader alone or city-specific industry leader alone (Reichelt and Wang, 2010). 


\section{REFERENCES}

Attolini, G, and Thompson, P. (2014), "The Evolution of an Accounting Practice: The Impact of Technology" IFAC Practice Management, Available from: https://www.ifac.org/globalknowledge-gateway/practice-management/discussion/evolution-accounting-practice-impact [Accessed 27 March 2017].

Audousset-Coulier, S., Jeny, A. and Jiang, L. (2016), 'The validity of auditor industry specialization measures'. Auditing: A Journal of Practice \& Theory, Vol. 35, No. 1, pp. 139-161.

Basioudis, I. G., and Francis, J. R. (2007), 'Big 4 audit fee premiums for national and office-level industry leadership in the United Kingdom'. Auditing: A Journal of Practice \& Theory, Vol. 26, No. 2, pp. 143-166.

Basioudis, I. G., Papakonstantinou, E. and Geiger, M. A. (2008), 'Audit fees, non-audit fees and auditor going-concern reporting decisions in the United Kingdom'. Abacus, Vol. 44, No. 3, pp. 284-309.

Berndt, E. R. (1991). The practice of econometrics: classic and contemporary. Addison-Wesley Publishing Co. Inc, USA.

Cahan, S. F., D. C. Jeter, and V. Naiker. (2011), 'Are all industry specialist auditors the same?' Auditing: A Journal of Practice \& Theory, Vol. 30, No. 4, pp. 191-222.

Carcello, J. V. and Nagy, A. L. (2004), 'Client size, auditor specialization and fraudulent financial reporting'. Managerial Auditing Journal, Vol. 19, No. 5, pp. 651-668.

Carson, E. and Fargher, N. (2007), 'Note on audit fee premiums to client size and industry specialization'. Accounting \& Finance, Vol. 47, No. 3, pp. 423-446.

Casterella, J., Francis, J., Lewis, B., and Walker, P. (2004), 'Auditor industry specialization, client bargaining power and audit pricing'. Auditing: A Journal of Practice \& Theory, Vol. 23, No. 1, pp. 49-66.

Causholli, M., De Martinis, M., Hay, D., Knechel, W. (2010), 'Audit markets, fees and production: Towards an integrated view of empirical audit research'. Journal of Accounting Literature, Vol. 30, pp. 167-215.

Chin, E. (2014), "Bigger. Better. Both? Limitless? Big Four strategic moves in consulting", Beaton Capital,14 April, Available from: http://www.beatoncapital.com/2014/04/limitless-big-fourstrategic-moves-consulting/ [Accessed 27 March 2017]. 
Choi, J., Kim, C., Kim, J. and Zang, Y. (2010), 'Audit office size, audit quality, and audit pricing', Auditing: A Journal of Practice \& Theory, Vol. 29, No.1, pp.73-97.

Craswell, A., Francis, J. and Taylor, S. (1995), 'Auditor brand name reputations and industry specializations'. Journal of Accounting and Economics, Vol. 20, pp. 297-322.

DeFond, M. L., Francis, J. R. and Wong, T. J. (2000), 'Auditor industry specialization and market segmentation: Evidence from Hong Kong'. Auditing: A Journal of Practice \& Theory, Vol. 19, No. 1, pp. 49-66.

DeFond, M. and Zhang, J. (2014), 'A review of archival auditing research'. Journal of Accounting and Economics, Vol. 58, Np. 2, pp. 275-326.

DeGeorge, E., Ferguson, C., and Spear, N. (2013), 'How much does IFRS cost? IFRS adoption and audit fees'. The Accounting Review, Vol. 88, No. 2, pp. 429-462.

Economist (2013), "Strategic moves: Big consulting and accounting firms are making a risky move into strategy work", Available from: http://www.economist.com/news/business/21589435-bigconsulting-and-accounting-firms-are-making-risky-move-strategy-work-strategic-moves [Accessed 27 March 2017].

Ettredge, M. and Greenberg, R. (1990), 'Determinants of fee cutting on initial audit engagements'. Journal of Accounting Research, Vol. 28, No. 1, pp. 198-210.

Ferguson, A. and Stokes, D. (2002), 'Brand name audit pricing, industry specialization and industry premiums post Big 8 and Big 6 mergers'. Contemporary Accounting Research, Vol. 19, pp. 77110.

Ferguson, A., Francis, J. R., and Stokes, D. J. (2003), 'The effects of firm-wide and office-level industry expertise on audit pricing'. The Accounting Review, Vol. 78, No. 2, pp. 429-448.

Firth, M. (2002). 'Auditor-Provided Consultancy Services and their Associations with Audit Fees and Audit Opinions'. Journal of Business Finance and Accounting, Vol. 29, No. 5-6, pp. 661-693

Francis, J, R., Stokes, D. J. and Anderson, D. (1999), 'City markets as a unit of analysis in audit research and the re-examination of Big 6 market shares'. Abacus, Vol. 35, pp. 185-206. 
Francis, J. R., Reichelt, K., and Wang, D. (2005), 'The pricing of national and city-specific reputations for industry expertise in the US audit market'. The Accounting Review, Vol. 80, No. 1, pp. 113136.

FRC (2010), “Audit firm governance”. Financial Reporting Council, London.

Fung, Y. K., Gul, F. A., and Krishnan, J. (2012), 'City-level auditor industry specialization, economies of scale, and audit pricing'. The Accounting Review, Vol. 87, No. 4, pp. 1281-1307.

GAO (2003), Public accounting firms: mandated study on consolidation and competition. Washington, DC: Government Accountability Office, Available from: http://www.gao.gov/new.items/d03864.pdf.

Geiger, M. A., and K. Raghunandan. (2001), 'Bankruptcies, audit reports, and the Reform Act'. Auditing: A Journal of Practice \& Theory, Vol. 20, No. 1, pp. 187-195.

Geiger, M. A., and D. V. Rama. (2003), 'Audit fees, non-audit fees, and auditor reporting on stressed companies'. Auditing: A Journal of Practice \& Theory, Vol. 22, No. 2, pp. 53-69.

Gow, I. D., Ormazabal, G. and Taylor, D. J. (2010), 'Correcting for cross-sectional and time-series dependence in accounting research'. The Accounting Review, Vol. 85, No. 2, pp. 483-512.

Habib, A. (2011), 'Audit firm industry specialization and audit outcomes: Insights from academic literature'. Research in Accounting Regulation, Vol. 23, pp. 114-129.

Hassan, O. A. G., Crawford, L. and Power, D. M. (2014), 'Audit fees, IFRS adoption and the recent global financial crisis'. Working paper, Brunel University.

Hay, D. and Jeter, D. (2011), 'The pricing of industry specialization by auditors in New Zealand'. Accounting and Business Research, Vol. 41, No. 2, pp. 171-195.

Hogan, C., and D. Jeter. (1999), 'Industry specialization by auditors', Auditing: A Journal of Practice \& Theory, Vol. 5, No.1, pp. 1-17.

Hopwood, W., McKeown, J.C., and Mutchler, J. F. (1994), 'A re-examination of auditor versus model accuracy within the context of the going-concern opinion decision'. Contemporary Accounting Research, Vol. 10, No. 2, pp. 409-431. 
Huang, H. W., Liu, L. L., Raghunandan, K., and Rama, D. (2007), 'Auditor industry specialization, client bargaining power and audit fees: Further evidence'. Auditing: A Journal of Practice \& Theory, Vol. 26, No. 1, pp. 147-158.

Kim J., Liu, X., and Zheng, L. (2012), 'The impact of mandatory IFRS adoption on audit fees: Theory and evidence'. The Accounting Review, Vol. 87, No. 6, pp. 2061-2094.

Krishnan, G.V. and Zhang, Y (2013), 'Is There a Relation between Audit Fee Cuts During the Global Financial Crisis and Banks' Financial Reporting Quality?'. Journal of Accounting and Public Policy, Vol 33, No 3, pp. 279-300.

Mayhew, B. W. and Wilkins, M. S. (2003), 'Audit firm industry specialization as a differentiation strategy: Evidence from fees charges to firms going public'. Auditing: A Journal of Practice \& Theory, Vol. 22, No. 2, pp. 33-52.

Minutti-Meza, M. (2013), 'Does auditor industry specialization improve audit quality?' Journal of Accounting Research, Vol. 51, No. 4, pp. 779-817.

Neal, T. L. and Riley Jr. R. R. (2004), 'Auditor industry specialist research design' . Auditing: A Journal of Practice \& Theory, Vol. 23, No. 2, pp. 169-177.

Numan, W. and Willekens, M. (2012), 'An empirical test of spatial competition in the audit market'. Journal of Accounting and Economics, Vol. 53, No. 1-2, pp. 450-465.

Pal, T. (2010). 'The impact of the economic crisis on auditing'. European Integration Studies, Miskolc, Vol. 8, No. 2, pp. 131-142.

Palmrose, Z. (1986), 'Audit fees and auditor size: further evidence'. Journal of Accounting Research Vol. 24, pp. 97-110.

Pearson, T. and Trompeter, G. (1994), 'Competition in the market for audit services: The effect of supplier concentration on audit fees'. Contemporary Accounting Research, Vol. 11, No. 1, pp. 91-114.

Petersen, M. A. (2009), 'Estimating standard errors in finance panel data sets: Comparing approaches'. Review of Financial Studies, Vol. 22, No. 1, pp. 435-480.

Reichelt, K., and Wang, D. (2010), 'National and office-specific measures of auditor industry expertise and effects on audit quality'. Journal of Accounting Research, Vol. 48, pp. 647-686. 
Reynolds, J. K., and Francis, J.R. (2000), 'Does size matter? The influence of large clients on officelevel auditor reporting decisions'. Journal of Accounting and Economics, Vol. 30, pp. 375-400.

Sikka, P. (2009). Financial crisis and the silence of the auditors. Accounting, Organizations and Society, Vol. 34, No. 6-7, pp. 868-873.

Srinidhi, B. and Gul, F. (2007), 'The Differential Effects of Auditors' Non-Audit and Audit Fees on Accrual Quality', Contemporary Accounting Research, Vol. 24, No. 2, pp. 595-629.

TCCAB (2011), Audit Quality and Transparency: A study of the usage and impact of public reports on audit governance: are they providing appropriate reassurance on audit quality?. The Consultative Committee of Accountancy Bodies, United Kingdom.

Thompson, S. (2006), 'Simple formulas for standard errors that cluster by both firm and time'. Journal of Financial Economics, Vol. 99, pp. 1-10.

Vera-Munoz, S., Ho, J. and Chow, C. (2006), 'Enhancing knowledge sharing in public accounting firms'. Accounting Horizons, Vol. 20, pp. 133-155.

Whisenant, S., S. Sankaraguruswamy, and K. Raghunandan. (2003), 'Evidence on the joint determination of audit and non-audit fees'. Journal of Accounting Research, Vol. 41, pp. 721744.

White, H., (1980), 'A heteroskedasticity-consistent covariance matrix estimator and a direct test for heteroskedasticity'. Econometrica, Vol. 48, pp. 817-838.

Xu, Y., Carson, E., Fargher, N. and Jiang, L. (2013), 'Responses by Australian auditors to the global financial crisis'. Accounting \& Finance, Vol. 53, pp. 301-338. 
TABLE 1

Selection Procedures for the Final Big 4 Sample

Description

Pooled

All LSE listed firms

22,217

Less: Financial firms

$(3,456)$

Less: Firms not followed by FAME database, public administration and defence,

health and education, other services firms, and firms with incomplete financial data

Full sample with complete data on audit fees

Less: Non-Big 4 sample

Big 4 sample

2,771

Less: Sample with less than two observations per city-industry combination

Final Big 4 sample 
TABLE 2

Sample Distribution based on the Pre, During and Post Financial Crisis Periods $(N=\mathbf{2 , 3 8 8})$

\begin{tabular}{|c|c|c|c|c|c|c|c|c|c|c|c|c|c|}
\hline & \multicolumn{4}{|c|}{$\begin{array}{c}\text { Pre financial crisis } \\
2004-2006(N=1,063)\end{array}$} & \multicolumn{4}{|c|}{$\begin{array}{c}\text { During financial crisis } \\
2007-2008(N=618)\end{array}$} & \multicolumn{4}{|c|}{$\begin{array}{l}\text { Post financial crisis } \\
2009-2011(N=707)\end{array}$} & \multirow{3}{*}{$\begin{array}{c}\text { T-Test } \\
\text { Mean Differences } \\
\text { between } \\
\text { Pre and Post } \\
\text { financial crisis } \\
\text { periods }\end{array}$} \\
\hline & \multirow[b]{2}{*}{$\begin{array}{l}\text { No. of } \\
\text { clients } \\
(\mathrm{N})\end{array}$} & \multicolumn{3}{|c|}{ Average } & \multirow[b]{2}{*}{$\begin{array}{l}\text { No. of } \\
\text { clients } \\
\text { (N) }\end{array}$} & \multicolumn{3}{|c|}{ Average } & \multirow[b]{2}{*}{$\begin{array}{l}\text { No. of } \\
\text { clients } \\
(\mathrm{N})\end{array}$} & \multicolumn{3}{|c|}{ Average } & \\
\hline & & $\begin{array}{c}\text { Client's } \\
\text { total } \\
\text { assets } \\
(£ \text { mil) }\end{array}$ & $\begin{array}{c}\text { Audit } \\
\text { fees } \\
(£ \text { mil) }\end{array}$ & $\begin{array}{c}\text { Non- } \\
\text { audit } \\
\text { fees } \\
(\mathfrak{E} \text { mil) }\end{array}$ & & $\begin{array}{c}\text { Client's } \\
\text { total } \\
\text { assets } \\
\text { (£ mil) }\end{array}$ & $\begin{array}{c}\text { Audit } \\
\text { fees } \\
(£ \text { mil) }\end{array}$ & $\begin{array}{c}\text { Non- } \\
\text { audit } \\
\text { fees } \\
\text { (£ mil) }\end{array}$ & & $\begin{array}{c}\text { Client's } \\
\text { total } \\
\text { assets } \\
(£ \text { mil) }\end{array}$ & $\begin{array}{c}\begin{array}{c}\text { Audit } \\
\text { fees } \\
(\mathfrak{m} \text { mil })\end{array} \\
\end{array}$ & $\begin{array}{c}\text { Non- } \\
\text { audit } \\
\text { fees } \\
\text { (£ mil) }\end{array}$ & \\
\hline BIG 4 & 1,063 & 2,423 & 0.854 & 0.815 & 618 & 3,311 & 0.984 & 0.662 & 707 & 4,254 & 1.110 & 0.603 & $\begin{array}{l}2.71 * * * \\
1.92 * \\
1.51\end{array}$ \\
\hline $\mathrm{PwC}$ & 341 & 3,332 & 1.137 & 0.982 & 181 & 5,490 & 1.524 & 0.976 & 212 & 7,609 & 1.845 & 0.936 & $\begin{array}{l}2.76^{* * * *} \\
2.30^{* *} \\
0.27\end{array}$ \\
\hline $\mathrm{DE}$ & 279 & 1,818 & 0.518 & 0.521 & 171 & 2,098 & 0.651 & 0.411 & 180 & 1,583 & 0.621 & 0.424 & $\begin{array}{l}0.30 \\
1.03 \\
1.01\end{array}$ \\
\hline KPMG & 288 & 1,482 & 0.669 & 0.549 & 166 & 1,452 & 0.598 & 0.429 & 196 & 1,610 & 0.605 & 0.356 & $\begin{array}{l}0.31 \\
0.56 \\
2.21 * *\end{array}$ \\
\hline EY & 155 & 3,263 & 1.183 & 1.456 & 100 & 4,527 & 1.218 & 0.910 & 119 & 6,671 & 1.372 & 0.685 & $\begin{array}{l}1.31 \\
0.36 \\
0.97\end{array}$ \\
\hline
\end{tabular}

*** significant at $p<.01, * *$ significant at $p<.05$ and $*$ significant at $p<.10$ respectively.

Definition of Big Accounting Firms:

$\mathrm{PWC}=$ PricewaterhouseCoopers $; \mathrm{DE}=$ Deloitte $\&$ Touche $; \mathrm{KP}=\mathrm{KPMG} ; \mathrm{EY}=$ Ernst $\&$ Young 
TABLE 3

Descriptive Statistics for the Sample Data and for the Period 2004-2011

Big 4 Sample $(N=2,388)$

\begin{tabular}{|c|c|c|c|c|c|c|c|c|c|c|}
\hline & & \multicolumn{5}{|c|}{ JUINI Sample $(N=65 t)$} \\
\hline & Mean & Median & Std. Dev. & Q1 & Q3 & Mean & Median & Std. Dev. & Q1 & Q3 \\
\hline$L A F$ & 5.419 & 5.319 & 0.635 & 4.954 & 5.845 & 5.639 & 5.477 & 0.684 & 5.121 & 6.204 \\
\hline LTA & 8.444 & 8.384 & 0.940 & 7.761 & 9.126 & 8.739 & 8.716 & 1.013 & 7.941 & 9.523 \\
\hline SQRTSUBS & 5.259 & 4.060 & 4.001 & 2.450 & 6.856 & 5.851 & 4.360 & 4.439 & 2.828 & 7.810 \\
\hline$\widetilde{C A T A}$ & 0.467 & 0.461 & 0.233 & 0.293 & 0.625 & 0.434 & 0.438 & 0.219 & 0.260 & 0.590 \\
\hline QUICK & 2.093 & 1.132 & 4.106 & 0.771 & 1.755 & 1.636 & 1.023 & 3.500 & 0.665 & 1.480 \\
\hline$\widetilde{D} E$ & 0.179 & 0.144 & 0.174 & 0.010 & 0.290 & 0.197 & 0.180 & 0.173 & 0.037 & 0.308 \\
\hline$R O I$ & 0.039 & 0.070 & 0.208 & 0.010 & 0.126 & 0.057 & 0.075 & 0.182 & 0.020 & 0.127 \\
\hline FOREIGN & 0.316 & 0.050 & 0.389 & 0 & 0.726 & 0.292 & 0.041 & 0.376 & 0 & 0.642 \\
\hline OPINION & 0.044 & 0 & 0.204 & 0 & 0 & 0.040 & 0 & 0.195 & 0 & 0 \\
\hline$B U S Y$ & 0.657 & 1.000 & 0.475 & 0 & 1.000 & 0.656 & 1.000 & 0.475 & 0 & 1.000 \\
\hline LOSS & 0.297 & 0 & 0.457 & 0 & 1.000 & 0.399 & 0 & 0.490 & 0 & 1.000 \\
\hline$L N A F$ & 4.929 & 5.170 & 1.436 & 4.610 & 5.725 & 4.985 & 5.155 & 1.280 & 4.602 & 5.720 \\
\hline$\angle O N D O N$ & 0.363 & 0 & 0.481 & 0 & 1.000 & 0.335 & 0 & 0.472 & 0 & 1.000 \\
\hline \multirow[t]{3}{*}{ INITIAL } & 0.329 & 0 & 0.470 & 0 & 1.000 & 0.338 & 0 & 0.473 & 0 & 1.000 \\
\hline & \multicolumn{5}{|c|}{ CITY_ONLY Sample $(N=428)$} & \multicolumn{5}{|c|}{ NAT_ONLY Sample $(N=173)$} \\
\hline & Mean & Median & Std. Dev. & Q1 & Q3 & Mean & Median & Std. Dev. & Q1 & Q3 \\
\hline$L A F$ & 5.291 & 5.300 & 0.555 & 4.908 & 5.610 & 5.246 & 5.146 & 0.584 & 4.919 & 5.504 \\
\hline LTA & 8.249 & 8.215 & 0.829 & 7.676 & 8.763 & 8.149 & 8.004 & 0.850 & 7.561 & 8.692 \\
\hline SQRTSUBS & 5.356 & 4.122 & 3.957 & 2.450 & 7.089 & 5.358 & 3.873 & 3.932 & 2.646 & 7.071 \\
\hline CATA & 0.497 & 0.506 & 0.227 & 0.350 & 0.640 & 0.541 & 0.572 & 0.237 & 0.352 & 0.686 \\
\hline QUICK & 2.109 & 1.234 & 3.858 & 0.851 & 1.940 & 2.002 & 1.311 & 3.307 & 0.860 & 1.910 \\
\hline$D E$ & 0.179 & 0.151 & 0.177 & 0.009 & 0.294 & 0.165 & 0.130 & 0.168 & 0.010 & 0.261 \\
\hline$R O I$ & 0.027 & 0.067 & 0.212 & 0.017 & 0.117 & 0.036 & 0.067 & 0.201 & 0 & 0.140 \\
\hline FOREIGN & 0.319 & 0.062 & 0.382 & 0 & 0.686 & 0.305 & 0.088 & 0.365 & 0 & 0.670 \\
\hline OPINION & 0.056 & 0 & 0.230 & 0 & 0 & 0.035 & 0 & 0.184 & 0 & 0 \\
\hline$B U S Y$ & 0.612 & 1.000 & 0.488 & 0 & 1.000 & 0.601 & 1.000 & 0.491 & 0 & 1.000 \\
\hline LOSS & 0.435 & 0 & 0.496 & 0 & 1.000 & 0.410 & 0 & 0.493 & 0 & 1.000 \\
\hline$L N A F$ & 4.903 & 5.068 & 1.380 & 4.565 & 5.699 & 5.033 & 5.301 & 1.455 & 4.663 & 5.845 \\
\hline LONDON & 0.350 & 0 & 0.478 & 0 & 1.000 & 0.341 & 0 & 0.475 & 0 & 1.000 \\
\hline INITIAL & 0.430 & 0 & 0.496 & 0 & 1.000 & 0.179 & 0 & 0.385 & 0 & 0 \\
\hline
\end{tabular}

Variable Definitions:

$L A F=$ natural log of audit fees in GBP'000; $L T A=$ natural log of total assets in GBP'000; $S Q R T S U B S=$ square root of total subsidiaries; $C A T A=$ ratio of current assets to total assets; $Q U I C K=$ ratio of current assets (less inventories) to current liabilities; $D E=$ ratio of long-term debt to total assets; $R O I=$ ratio of earnings before interest and tax to total assets; $F O R E I G N=$ proportion of total sales from foreign operations; $O P I N I O N=$ indicator variable, $1=$ qualified and going-concern audit report, $0=$ otherwise; $B U S Y=$ indicator variable, $1=$ December 31 st or March 31 st year-end, $0=$ otherwise; $L O S S$ $=$ indicator variable, $1=$ loss in any of the past three years, $0=$ otherwise; $L N A F=$ natural log of non-audit fees (in GBP'000) paid to the auditor; $L O N D O N=$ indicator variable, $1=$ if observation is a

London-based company, $0=$ otherwise; and INITIAL = indicator variable, $1=$ if the audit engagement is in either the first or second year, $0=$ otherwise; and $N A T=$ indicator variable, $1=$ companies audited by the Big 4 national industry leaders, $0=$ otherwise; and $C I T Y=$ indicator variable, $1=$ companies audited by the Big 4 city-specific industry leaders, $0=$ otherwise; and $J O I N T=$ indicator variable, $1=$ companies audited by auditors that are joint (both) the national industry leader and the city-specific industry leader, $0=$ otherwise; and $C I T Y \_O N L Y=$ indicator variable, $1=$ companies audited by the cityspecific industry leader alone, without also being the national industry leader, $0=$ otherwise; and $N A T \_O N L Y=$ indicator variable, $1=$ companies audited by the national industry leader alone, without also being the city-specific industry leader, $0=$ otherwise. 
TABLE 4

Correlation matrix

\begin{tabular}{|c|c|c|c|c|c|c|c|c|c|c|c|c|c|}
\hline & $L A F$ & $L N A F$ & $L T A$ & SQRTSUBS & $R O I$ & $L E V$ & FOREIGN & $Q U I C K$ & CATA & OPINION & $L O N D O N$ & $B U S Y$ & $L O S S$ \\
\hline$L A F$ & 1 & & & & & & & & & & & & \\
\hline$L N A F$ & $0.57 * *$ & 1 & & & & & & & & & & & \\
\hline$L T A$ & $0.90 * *$ & $0.54 * *$ & 1 & & & & & & & & & & \\
\hline SQSRTSUBS & $0.66^{* *}$ & $0.41 * *$ & $0.62 * *$ & 1 & & & & & & & & & \\
\hline$\widehat{R O I}$ & $0.30 * *$ & $0.20 * *$ & $0.43 * *$ & $0.25 * *$ & 1 & & & & & & & & \\
\hline$L E V$ & $0.40 * *$ & $0.26^{* *}$ & $0.43^{* *}$ & $0.37 * *$ & $0.16^{* *}$ & 1 & & & & & & & \\
\hline FOREIGN & $0.18 * *$ & $0.09 * *$ & $0.10 * *$ & $0.04 * *$ & 0.02 & $0.06 * *$ & 1 & & & & & & \\
\hline$Q U I C K$ & $-0.29 * *$ & $-0.22 * *$ & $-0.24 * *$ & $-0.20 * *$ & $-0.14 * *$ & $-0.22 * *$ & $-0.08 * *$ & 1 & & & & & \\
\hline CATA & $-0.18 * *$ & $-0.04 * *$ & $-0.27 * *$ & $-0.06 * *$ & $-0.07 * *$ & $-0.3 * *$ & $-0.05 * *$ & $0.21 * *$ & 1 & & & & \\
\hline OPINION & $-0.13^{* *}$ & $-0.16^{* *}$ & $-0.18 * *$ & $-0.13 * *$ & $-0.25^{* *}$ & $-0.06^{* *}$ & 0.01 & $0.05 * *$ & $-0.07 * *$ & 1 & & & \\
\hline$\angle O N D O N$ & 0.01 & $-0.05 * *$ & -0.01 & $-0.06 * *$ & $-0.10 * *$ & $-0.05 * *$ & $0.08 * *$ & $0.14 * *$ & $-0.12 * *$ & $0.09 * *$ & 1 & & \\
\hline$B U S Y$ & $0.11 * *$ & $0.08 * *$ & $0.08 * *$ & $0.07 * *$ & 0.00 & $0.03 * *$ & $0.09 * *$ & 0.014 & $-0.04 * *$ & 0.01 & $0.097 * *$ & 1 & \\
\hline$L O S S$ & $-0.33 * *$ & $-0.21 * *$ & $-0.41 * *$ & $-0.20 * *$ & $-0.41 * *$ & $-0.12 * *$ & -0.01 & $0.22 * *$ & $0.05^{* *}$ & $0.15^{* *}$ & $0.102 * *$ & 0.01 & 1 \\
\hline INITIAL & $-0.15^{* *}$ & $-0.10 * *$ & $-0.16^{* *}$ & $-0.03 * *$ & $-0.08 * *$ & -0.02 & $-0.06 * *$ & $0.08 * *$ & 0.00 & 0.01 & 0.011 & $-0.02 *$ & $0.15^{* *}$ \\
\hline$N A T$ & $0.15^{* *}$ & $0.07 * *$ & $0.13^{* *}$ & $0.08 * *$ & $0.05 * *$ & $0.04 * *$ & $-0.04 * *$ & $-0.06 * *$ & -0.03 & -0.01 & -0.023 & 0.01 & $-0.04 * *$ \\
\hline CITY & $0.11 * *$ & $0.04 * *$ & $0.09 * *$ & $0.09 * *$ & 0.030 & $0.05 * *$ & -0.03 & $-0.06^{* *}$ & -0.03 & 0.01 & $-0.072 * *$ & 0.01 & -0.03 \\
\hline JOINT & $0.21 * *$ & $0.09 * *$ & $0.19 * *$ & $0.09 * *$ & $0.05 * *$ & $0.06^{* *}$ & -0.03 & $-0.06 * *$ & $-0.08^{* *}$ & -0.01 & 0.008 & 0.02 & $-0.06^{* *}$ \\
\hline CITY_ONLY & $-0.09 * *$ & $-0.05 * *$ & $-0.09 * *$ & 0.01 & -0.02 & 0.00 & 0.00 & 0.00 & $0.05^{* *}$ & 0.02 & $-0.103 * *$ & -0.01 & 0.02 \\
\hline \multirow[t]{2}{*}{ NAT_ONLY } & $-0.07 * *$ & -0.02 & $-0.08^{* *}$ & 0.01 & -0.01 & -0.02 & -0.01 & -0.00 & $0.08^{* *}$ & -0.01 & $-0.056^{* *}$ & -0.01 & 0.02 \\
\hline & INITIAL & NAT & $C I T Y$ & JOINT & $\begin{array}{l}\text { CITY } \\
\text { ONLY }\end{array}$ & $\begin{array}{l}\text { NAT } \\
\text { ONLY }\end{array}$ & & & & & & & \\
\hline INITIAL & 1 & & & & & & & & & & & & \\
\hline NAT & 0.03 & 1 & & & & & & & & & & & \\
\hline$C I T Y$ & -0.02 & $0.49 * *$ & 1 & & & & & & & & & & \\
\hline JOINT & -0.00 & $0.84 * *$ & $0.67 * *$ & 1 & & & & & & & & & \\
\hline CITY_ONLY & -0.01 & $-0.34 * *$ & $0.51 * *$ & $-0.28 * *$ & 1 & & & & & & & & \\
\hline NAT_ONLY & $0.07 * *$ & $0.38 * *$ & $-0.25 * *$ & $-0.17 * *$ & $-0.13^{* *}$ & 1 & & & & & & & \\
\hline
\end{tabular}

*** significant at $p<.01, * *$ significant at $p<.05$ and *significant at $p<.10$ respectively.

Variable Definitions:

$L A F=$ natural $\log$ of audit fees in GBP'000; $L T A=$ natural $\log$ of total assets in GBP'000; SQRTSUBS = square root of total subsidiaries; $C A T A=$ ratio of current assets to total assets; $Q U I C K=$ ratio of current assets (less inventories) to current liabilities; $D E=$ ratio of long-term debt to total assets; $R O I=$ ratio of earnings before interest and tax to total assets; $F O R E I G N=$ proportion of total sales from foreign operations; OPINION = indicator variable, $1=$ qualified and going-concern audit report, $0=$ otherwise; $B U S Y=$ indicator variable, $1=$ December 31 st or March 31 st year-end, $0=$ otherwise; $L O S S$ $=$ indicator variable, $1=$ loss in any of the past three years, $0=$ otherwise; $L N A F=$ natural $\log$ of non-audit fees (in GBP' 000 ) paid to the auditor; $L O N D O N=$ indicator variable, $1=$ if observation is a

London-based company, $0=$ otherwise; and $I N I T I A L=$ indicator variable, $1=$ if the audit engagement is in either the first or second year, $0=$ otherwise; and $N A T=$ indicator variable, $1=$ companies audited by the Big 4 national industry leaders, $0=$ otherwise; and $C I T Y=$ indicator variable, $1=$ companies audited by the Big 4 city-specific industry leaders, $0=$ otherwise; and $J O I N T=$ indicator variable, $1=$ companies audited by auditors that are joint (both) the national industry leader and the city-specific industry leader, $0=$ otherwise; and $C I T Y \_O N L Y=$ indicator variable, $1=$ companies audited by the cityspecific industry leader alone, without also being the national industry leader, $0=$ otherwise; and $N A T_{-} O N L Y=$ indicator variable, $1=$ companies audited by the national industry leader alone, without also being the city-specific industry leader, $0=$ otherwise. 
TABLE 5

Effects of Big 4 National and City-Specific Industry Leadership on Audit Fee Premium Relative to Big 4 Non-Leaders for the Period 2004-2011 ${ }^{\mathrm{a}}$

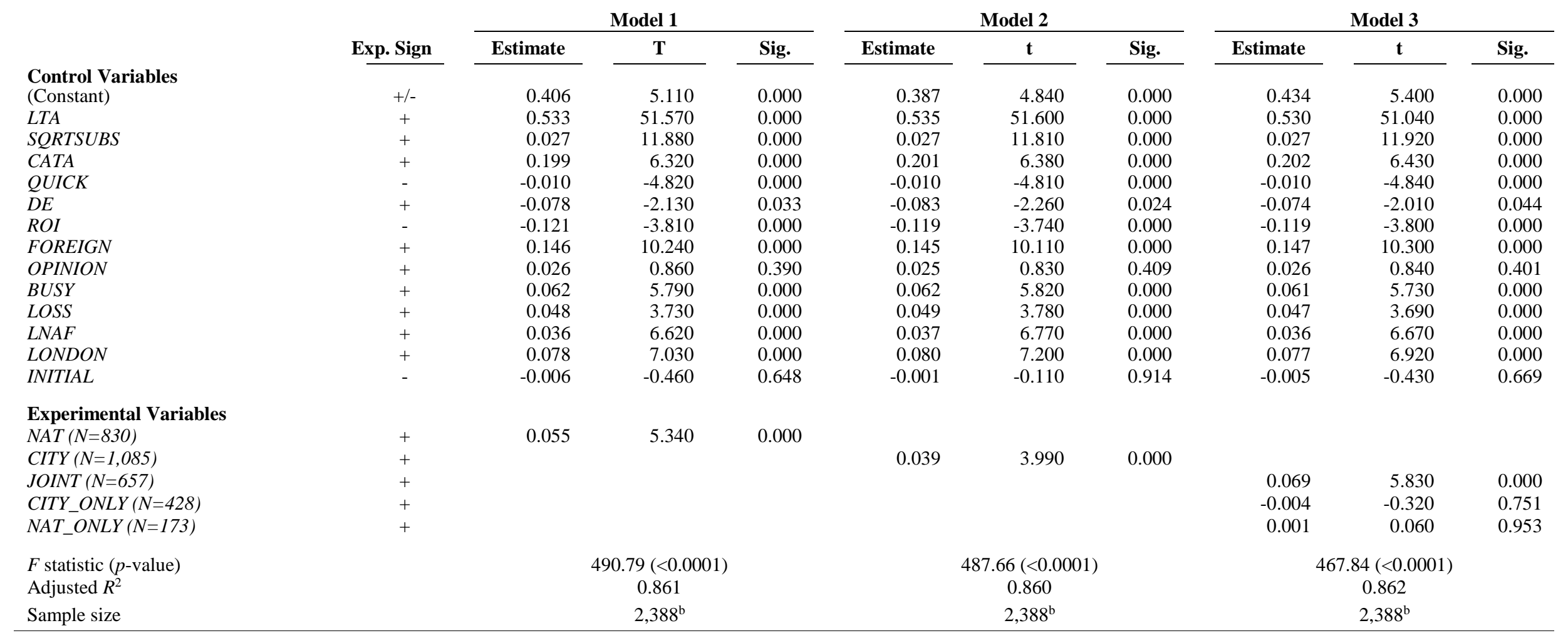

${ }^{a}$ All p-values are two-tailed. Industry fixed-effects and year fixed-effects are not reported for brevity, and t-statistics and significance levels are calculated using the White (1980) robust standard errors to correct for heteroscedasticity.

${ }^{\text {b }}$ The sample comprises 2,388 observations of U.K. public listed companies that are audited by Big 4 auditors. The sample size is derived after deleting 383 observations with less than two city-specific observations per industry from the initial Big 4 sample ( $\mathrm{N}=2,771$ as reported in Table 1). This additional screening is performed as to ensure that the audit market for the all the cities in specific industries analysed is competitive where more than one audit client exists.

Variable Definitions:

$L A F=$ natural $\log$ of audit fees in GBP'000; $L T A=$ natural $\log$ of total assets in GBP'000; SQRTSUBS = square root of total subsidiaries; $C A T A=$ ratio of current assets to total assets; $Q U I C K=$ ratio of current assets (less inventories) to current liabilities; $D E=$ ratio of long-term debt to total assets; $R O I=$ ratio of earnings before interest and tax to total assets; $F O R E I G N=$ proportion of total sales from foreign operations; $O P I N I O N=$ indicator variable, $1=$ qualified and going-concern audit report, $0=$ otherwise; $B U S Y=$ indicator variable, $1=$ December 31 st or March 31 st year-end, $0=$ otherwise; $L O S S$ $=$ indicator variable, $1=$ loss in any of the past three years, $0=$ otherwise; $L N A F=$ natural log of non-audit fees (in GBP'000) paid to the auditor; $L O N D O N=$ indicator variable, $1=$ if observation is a London-based company, $0=$ otherwise; and $I N I T I A L=$ indicator variable, $1=$ if the audit engagement is in either the first or second year, $0=$ otherwise; and $N A T=$ indicator variable, $1=$ companies audited by the Big 4 national industry leaders, $0=$ otherwise; and $C I T Y=$ indicator variable, $1=$ companies audited by the Big 4 city-specific industry leaders, $0=$ otherwise; and $J O I N T=$ indicator variable, $1=$ companies audited by auditors that are joint (both) the national industry leader and the city-specific industry leader, $0=$ otherwise; and $C I T Y \_O N L Y=$ indicator variable, $1=$ companies audited by the cityspecific industry leader alone, without also being the national industry leader, $0=$ otherwise; and $N A T \_O N L Y=$ indicator variable, $1=$ companies audited by the national industry leader alone, without also being the city-specific industry leader, $0=$ otherwise. 
TABLE 6

Effects of Big 4 National and City-Specific Industry Leadership on Audit Fee Premium Relative to Big 4 Non-Leaders in the Pre, During and Post Financial Crisis Periods

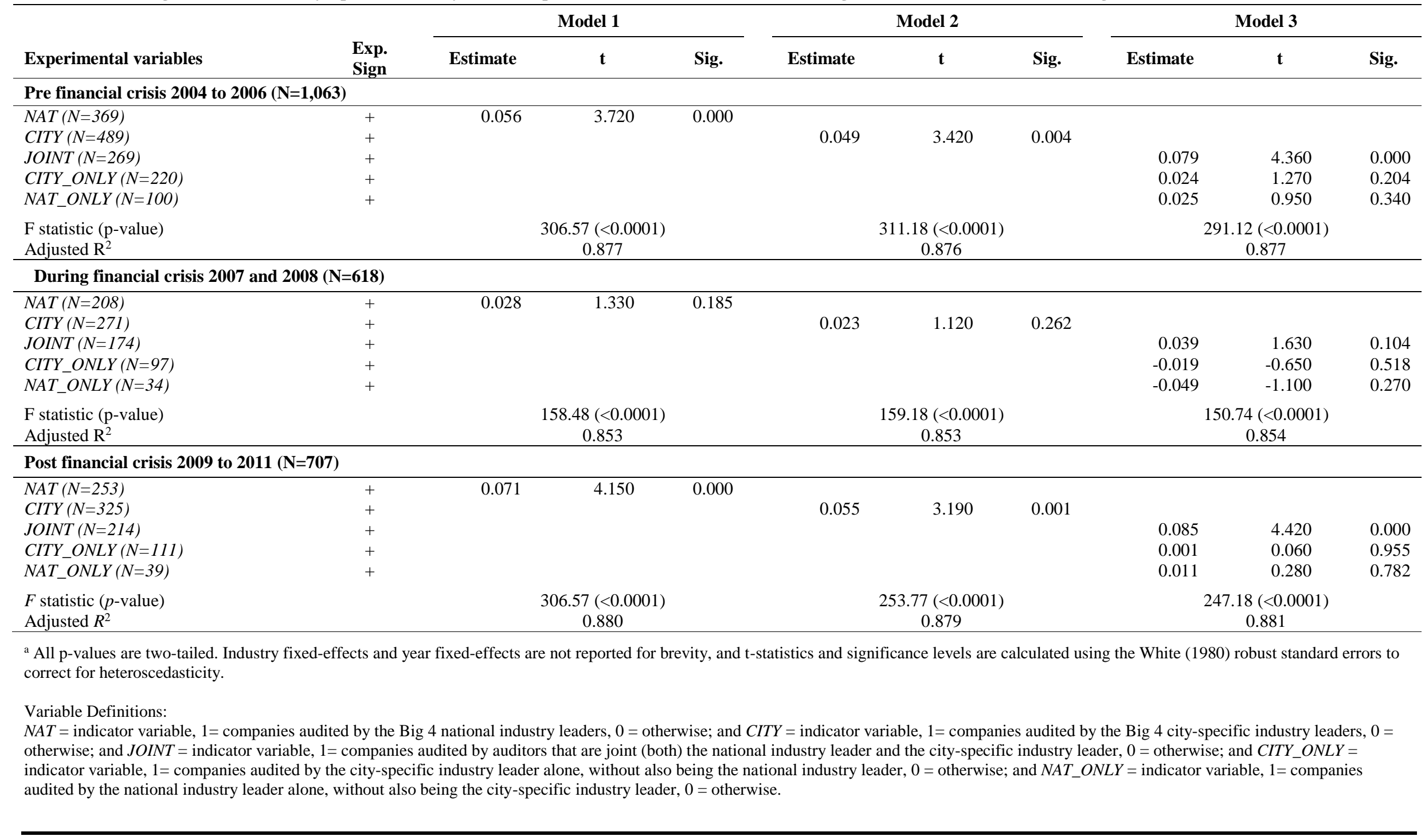


TABLE 7

Coefficients and Significance Levels of Specialization Variables in Robustness and Sensitivity Tests ${ }^{\mathrm{a}}$

\begin{tabular}{|c|c|c|c|c|c|c|c|c|c|}
\hline \multirow{2}{*}{\multicolumn{2}{|c|}{$\frac{\text { Model } 1}{N A T}$}} & \multirow{2}{*}{\multicolumn{2}{|c|}{$\begin{array}{c}\text { Model } 2 \\
C I T Y\end{array}$}} & \multicolumn{6}{|c|}{ Model 3} \\
\hline & & & & \multicolumn{2}{|c|}{ JOINT } & \multicolumn{2}{|c|}{ CITY_ONLY } & \multicolumn{2}{|c|}{ NAT_ONLY } \\
\hline Estimate & Sig. & Estimate & Sig. & Estimate & Sig. & Estimate & Sig. & Estimate & Sig. \\
\hline 0.053 & 0.000 & 0.042 & 0.000 & 0.068 & 0.000 & 0.000 & 0.995 & 0.003 & 0.892 \\
\hline 0.047 & 0.000 & 0.035 & 0.000 & 0.065 & 0.000 & -0.011 & 0.4887 & 0.016 & 0.268 \\
\hline 26.158 & 0.207 & 31.422 & 0.117 & 44.779 & 0.055 & -2.292 & 0.937 & -41.234 & 0.317 \\
\hline 76.256 & 0.000 & 59.536 & 0.007 & 97.720 & 0.000 & 0.042 & .0 .999 & -3.103 & 0.932 \\
\hline 0.036 & 0.001 & -0.007 & 0.476 & 0.030 & 0.013 & -0.061 & 0.000 & -0.012 & 0.480 \\
\hline 0.034 & 0.001 & -0.002 & 0.818 & 0.035 & 0.005 & -0.046 & 0.000 & -0.151 & 0.374 \\
\hline 0.075 & 0.000 & 0.049 & 0.001 & 0.083 & 0.000 & -0.013 & 0.569 & 0.014 & 0.730 \\
\hline 0.037 & 0.004 & 0.033 & 0.006 & 0.056 & 0.000 & 0.009 & 0.563 & 0.003 & 0.864 \\
\hline 0.062 & 0.000 & 0.029 & 0.047 & 0.069 & 0.000 & -0.024 & 0.205 & 0.007 & 0.781 \\
\hline 0.042 & 0.004 & 0.047 & 0.001 & 0.061 & 0.000 & 0.022 & 0.261 & -0.004 & 0.898 \\
\hline 0.050 & 0.001 & 0.029 & 0.040 & 0.055 & 0.001 & -0.008 & 0.694 & 0.020 & 0.562 \\
\hline 0.051 & 0.000 & 0.044 & 0.001 & 0.075 & 0.000 & 0.000 & 0.993 & -0.013 & 0.571 \\
\hline
\end{tabular}

Drop incompetitive audit market in

city-specific industies $(N=2,299)$

Alternative cut-off measures ${ }^{\mathrm{c}}$

Based on ranked $\operatorname{LAF}(N=2,388)$

Based on ranked $L A F$ and $L T A(N=2,388)$

Based on total assets market share $(N=2,388)$

Based on total sales market share $(N=2,388)$

Large client segment $(N=1,194)^{\mathrm{d}}$

Small client segment $(N=1,194)$

High risk client $(N=1,194)^{\mathrm{e}}$

Low risk client $(N=1,194)^{\mathrm{e}}$

High growth client $(N=1,1904)^{\mathrm{f}}$

Low growth client $(N=1,194)^{i}$

0.000

0.044

0.001

0.075

0.000

${ }^{a}$ All p-values are two-tailed. Industry fixed-effects and year fixed-effects are not reported for brevity, and t-statistics and significance levels are calculated using the White (1980) robust standard errors to correct for heteroscedasticity.

${ }^{\mathrm{b}}$ Drop incompetitive audit market in city-specific industries $=$ The sample $(N=2,299)$ is derived after deleting 89 observations from 36 city- industry combinations where there is only one auditor.

${ }^{\mathrm{c}}$ For the national industry leadership, we follow Neal and Riley (2004) which define the minimum market share for industry leader as 1.2 times the inverse of the number of

Big $\mathrm{N}$ auditors $(1.2 \mathrm{X}$ 1/Big 4 audit firms) $=30$ percent. For the city-specific industry leadership, we follow Reichelt and Wang (2010) by replacing the the number of Big N auditors with the average number of auditor per city industry market, which computes to 48 percent $(1.2 \mathrm{X} 1 / 2.5)$, or approximately 50 percent.

${ }^{\mathrm{d}}$ Large (Small) client segment = companies with total assets above (below) the sample median of GBP £241.9 million.

${ }^{\mathrm{e}} \mathrm{High}$ (Low) risk client = companies with probability of bankruptcy score above (below) the sample median of 0.49 .

${ }^{\mathrm{f} H i g h}$ (Low) growth client = companies with market to book ratio above (below) the sample median of 0.89

Variable Definitions:

$N A T=$ indicator variable, $1=$ companies audited by the Big 4 national industry leaders, $0=$ otherwise; and $C I T Y=$ indicator variable, $1=$ companies audited by the Big 4 city-specific industry leaders, $0=$ otherwise; and $J O I N T=$ indicator variable, $1=$ companies audited by auditors that are joint (both) the national industry leader and the city-specific industry leader, $0=$ otherwise; and $C I T Y \quad O N L Y=$

indicator variable, $1=$ companies audited by the city-specific industry leader alone, without also being the national industry leader, $0=$ otherwise; and $N A T \_O N L Y=$ indicator variable, $1=$ companies audited by the national industry leader alone, without also being the city-specific industry leader, $0=$ otherwise. 
${ }^{1}$ The term industry leader and industry specialist are used interchangeably throughout the paper.

${ }^{2}$ In addition, as a sensitivity analysis reported in later part of the paper, we drop each Big 4 audit firm and each of the 13 industries one at a time and the results are qualitatively unchanged, which indicates that individual Big 4 firms and individual industries do not drive the results. ${ }^{3}$ Since the tragedy of Great Depression in 1929-1933, the GFC which started in 2007 is one of the most significant economic events ever recorded in the history (Pal, 2010).

${ }^{4}$ FAME is an acronym for "Financial Analysis Made Easy," a comprehensive database for U.K. private and publicly-listed companies maintained by Bureau Van Dijk.

5 As the financial statement data and related ratios used for public listed companies in the financial services sectors qualitatively differ from other sectors, these companies are excluded from the sample.

${ }^{6}$ For sensitivity check in the later part of the paper, we also run similar analysis on the sample using the LSE's two-digit SIC codes as used in Basioudis and Francis (2007), and the results are qualitatively the same.

${ }^{7}$ The three largest cities after London are Birmingham (eight percent), Manchester and Leeds (both at seven percent), while the remaining London-based companies are audited by audit offices not far away outside of London. 77 percent of the sample companies are located in 51 cities outside of London and are audited by non-London offices of the audit firms.

${ }^{8}$ Following Berndt (1991, p. 164), the percentage magnitude of the positive intercept shift on the dependent variable (natural log of audit fees) is defined as $\mathrm{e}^{\mathrm{z}}-1$, where $\mathrm{z}$ is the auditor coefficient value in the regression model.

${ }^{9}$ ibid.

${ }^{10}$ When we run the regressions (untabulated) on a yearly basis using the LSE's two-digit SIC Codes industry classification as per Basioudis and Francis (2007), we find that the city-specific industry premium documented in Basioudis and Francis (2007) seems to be diminishing slowly, as there is still a slightly significant coefficient in 2004 and then it is completely wiped out in the following few years (at the $1 \%$ level of significance).

${ }^{11}$ We further test this proposition in the sensitivity analysis section.

${ }^{12}$ We use the value of the intercept as corrected by Geiger and Raghunandan (2001) which is -7.322 . 